\title{
ARBEIDSGIVERS TILRETTELEGGING FOR VARSLING
}

\author{
Kandidatnummer: 532 \\ Leveringsfrist: 25 . november 2008
}

Til sammen 17496 ord

28.11.2008 


\section{Innholdsfortegnelse}

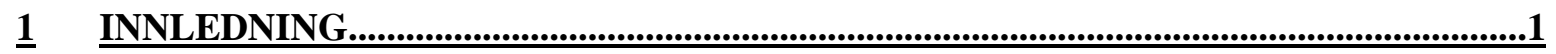

$1.1 \quad$ Presentasjon av tema og problemstilling .................................................................................1

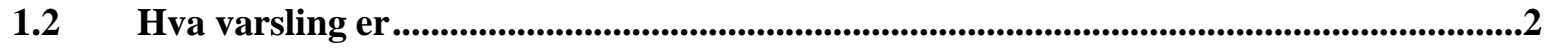

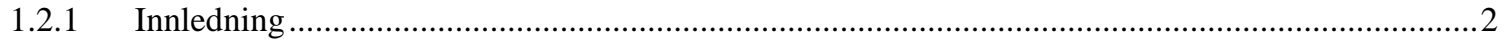

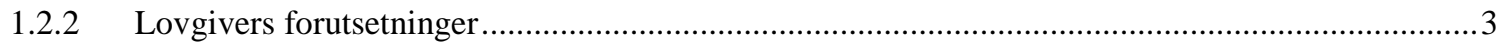

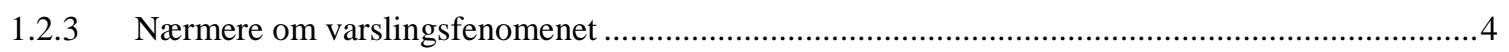

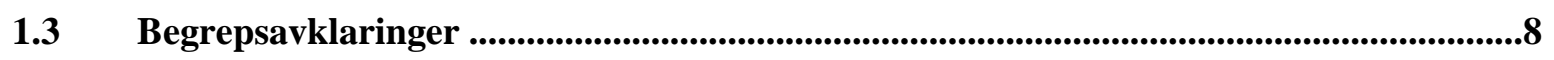

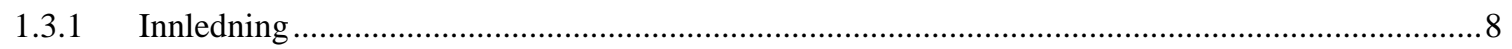

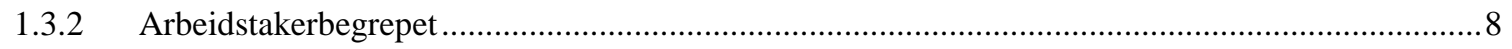

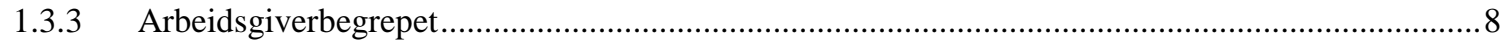

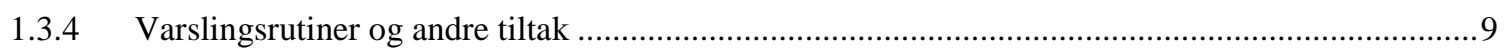

$1.4 \quad$ Avgrensning av oppgaven .............................................................................................................10

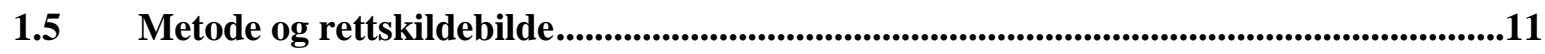

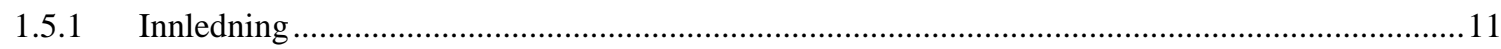

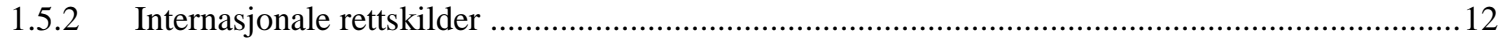

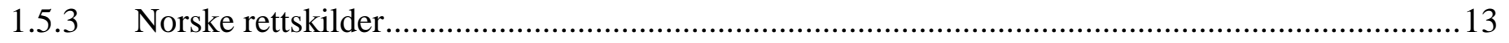

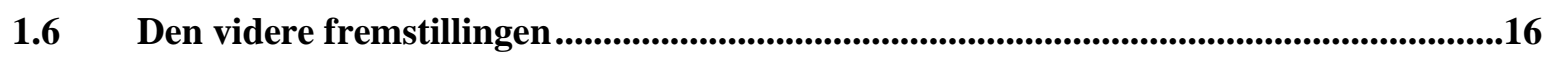

$\underline{2}$ GENERELLE HENSYN BAK VARSLINGSREGLENE............................................17

2.1 Om ytringsfriheten generelt ..........................................................................................................17

2.2 Formål og hensyn bak varslingsreglene spesielt .....................................................................18

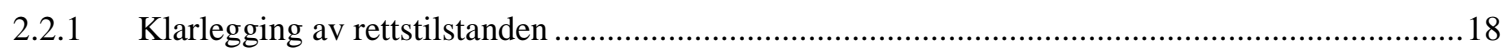

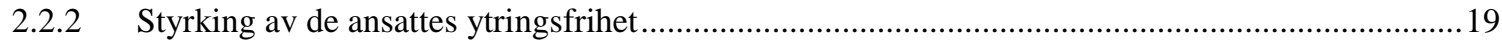

2.2.3 Virkemiddel for å avdekke og forebygge kritikkverdige forhold .................................................19 


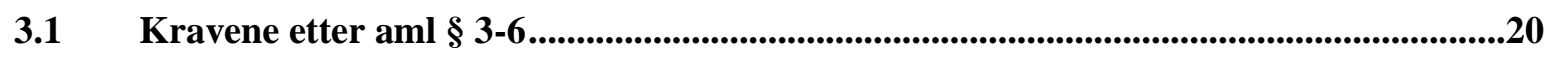

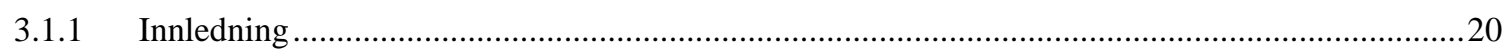

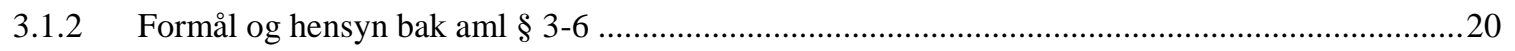

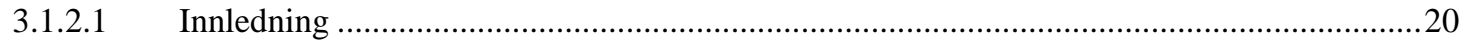

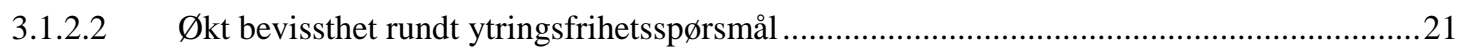

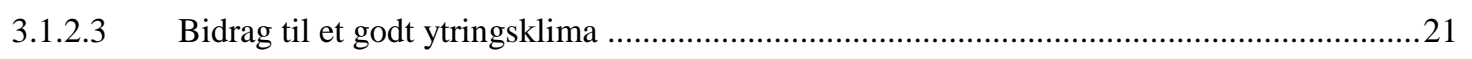

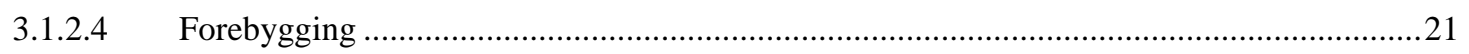

3.1.2.5 Styrke varsling som virkemiddel for avdekking av kritikkverdige forhold ..........................23

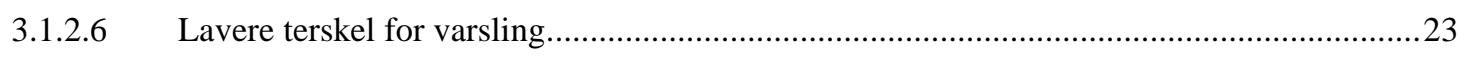

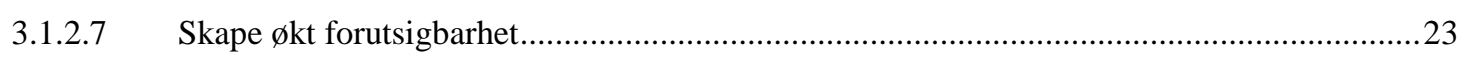

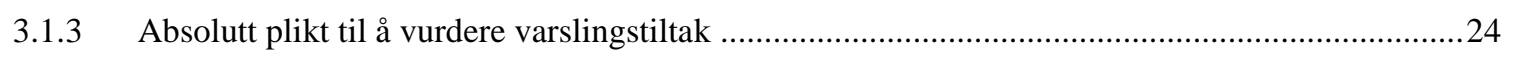

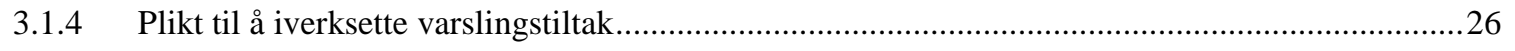

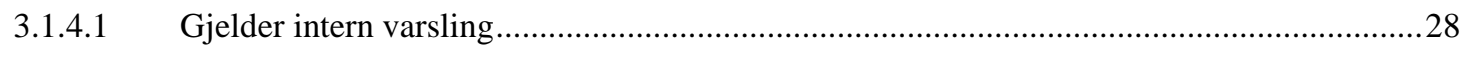

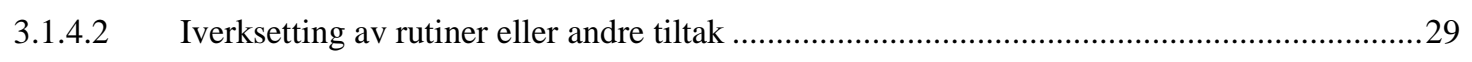

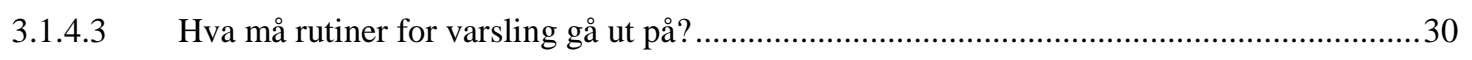

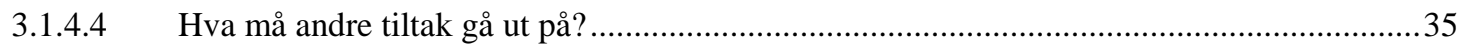

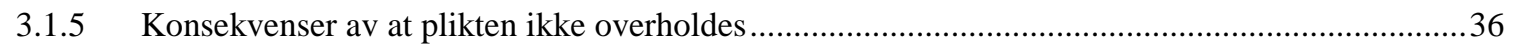

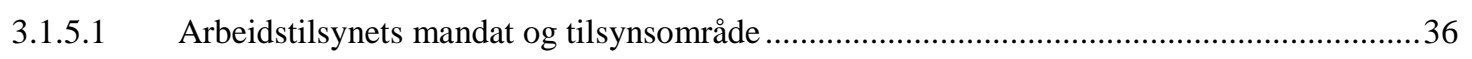

3.1.5.2 Arbeidstilsynets kontrollvirksomhet ……...................................................................... 36

3.2 Krav etter personopplysningsloven..............................................................................38

3.2.1 Varslingsrutiner og forholdet til personopplysningsloven ...............................................................38

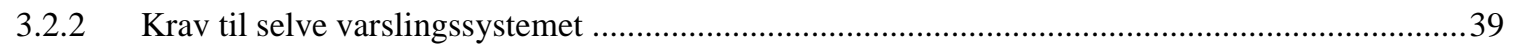

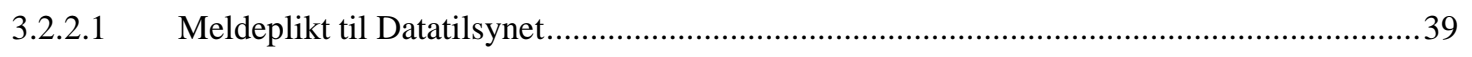

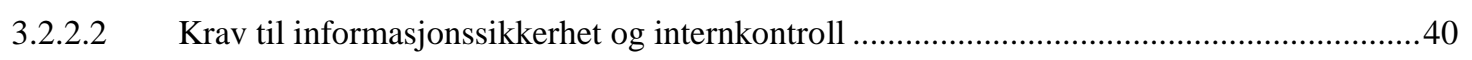

3.2.2.3 Må oppfylle kravene til informasjonssikkerhet .................................................................. 41

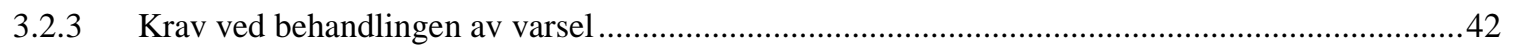

3.2.3.1 Hovedregelen om innsynsrett og informasjonsplikt ........................................................... 42

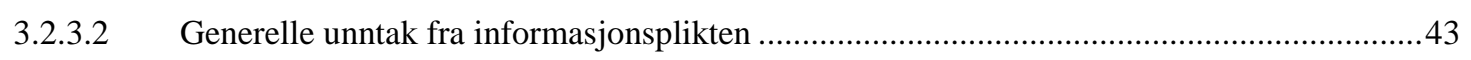

3.2.3.3 Spesielle unntak fra informasjonsplikten og innsynsretten ................................................. 43

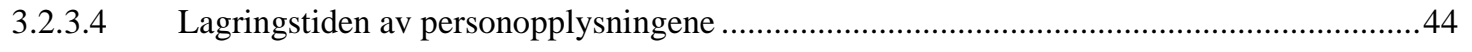

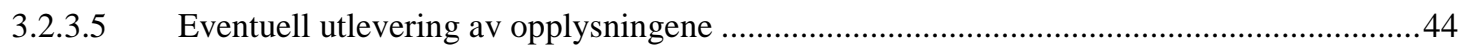

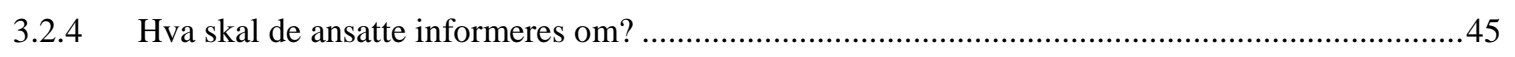

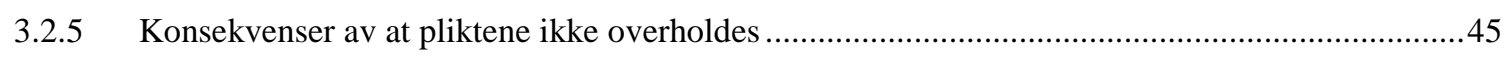




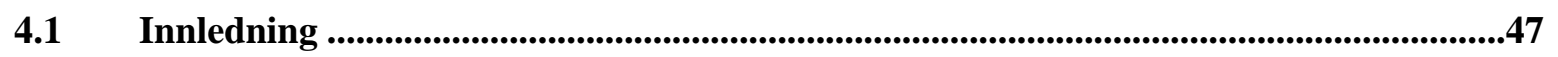

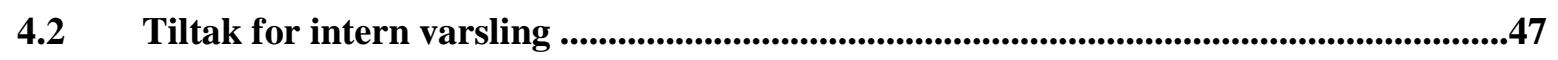

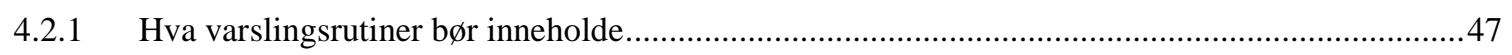

4.2.2 Særlig om tilrettelegging for anonym varsling ..................................................................... 49

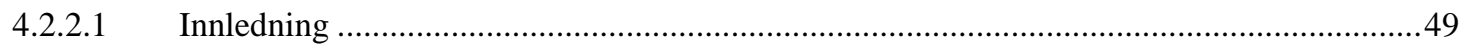

4.2.2.2 Forholdet til personopplysningsloven ...........................................................................51

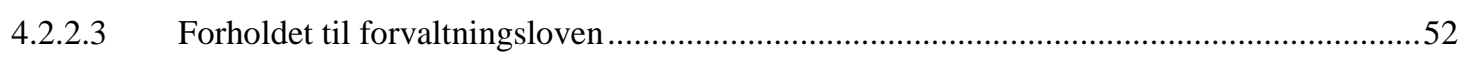

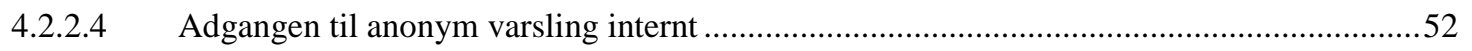

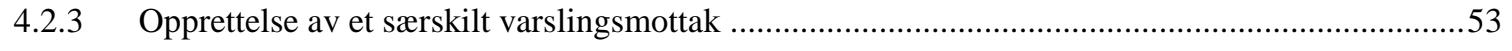

4.2.4 Opprettelse av et særskilt varslingsmottak ................................................................................54

4.3 Bør det legges til rette for varsling også fra tredjepart?...............................................55

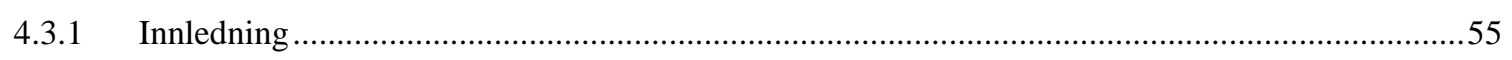

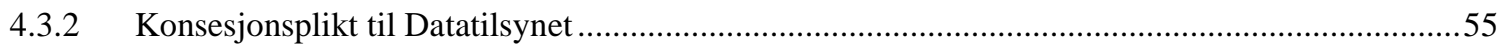

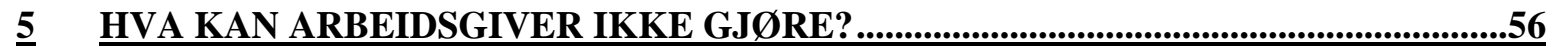

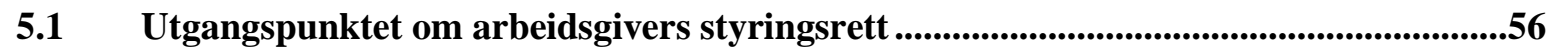

$5.2 \quad$ Begrensninger i arbeidsgivers styringsrett................................................................................56

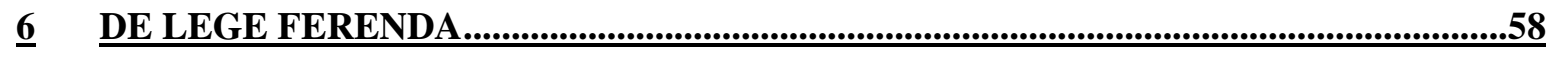

6.1 Noen utgangspunkter ....................................................................................................................58

6.2 Aml § 3-6 ...............................................................................................................................................59

6.3 Forholdet til personopplysningsloven ...............................................................................6

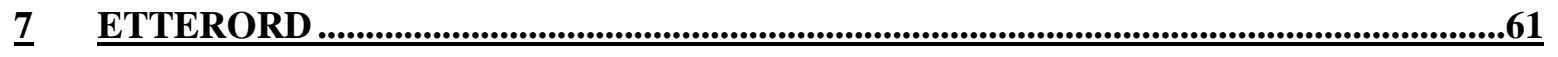




\section{Innledning}

\subsection{Presentasjon av tema og problemstilling}

Temaet for oppgaven er arbeidsgivers tilrettelegging for varsling. Det naturlige utgangspunktet må tas i § 3-6 i arbeidsmiljøloven (aml) av 17. juni 2005 nr. 62. Bestemmelsen trådte i kraft 1. januar 2007, som en av tre nye varslingsbestemmelser i arbeidsmiljøloven. Aml § 3-6 lyder slik:

”§ 3-6. Plikt til å legge forholdene til rette for varsling

Arbeidsgiver skal, i tilknytning til det systematiske helse-, miljø-og sikkerhetsarbeidet, utarbeide rutiner for intern varsling eller sette $i$ verk andre tiltak som legger forholdene til rette for intern varsling om kritikkverdige forhold $i$ virksomheten $i$ samsvar med \$ 2-4, dersom forholdene i virksomheten tilsier det."

Forslaget til aml § 3-6 ble første gang lansert i 2005 i en arbeidsgrupperapport fra Arbeidsog sosialdepartementet ${ }^{1}$. Under odelstingsdebatten i 2006 uttalte statsråd Hanssen at aml § 3-6 kanskje var den viktigste av de nye bestemmelsene:

"I hvilken grad arbeidstakerne faktisk er villige til å si fra om korrupsjon eller andre kritikkverdige forhold, handler antakeligvis ikke fфrst og fremst om den juridiske adgangen til å varsle, men vel så mye om «ytringskulturen» i bedriften og $i$ arbeidslivet.(...) Etter mitt syn er dette kanskje den viktigste bestemmelsen i proposisjonen. Denne regelen innebarer at arbeidsgiver må ta noen aktive grep for å sikre at intern kritikk og opplysninger om kritikkverdige forhold håndteres på en skikkelig måte $i$ virksomheten. Dette vil kunne

\footnotetext{
${ }^{1}$ Arbeidsgrupperapporten Ansattes ytringsfrihet, rapport av 21. desember 2005. Den nye aml § 3-6 er tilnærmet identisk med forslaget i rapporten.
} 
avverge konfliktfylte varslersaker, som er en stor belastning for virksomheten, for arbeidsmiljøet og ikke minst for varsleren selv. Og enda viktigere: Det vil gi arbeidstakerne signal om at det er фnskelig og normalt å si fra, slik at kritikkverdig praksis blir avdekket og ikke får utvikle seg. " 2 .

Det er et overordnet mål at varslingsreglene skal føre til en reell styrking av ytringsklimaet på norske arbeidsplasser. Den nye bestemmelsen i aml § 3-6, som pålegger arbeidsgiver å legge til rette for de ansattes varsling, er en understreking av at det først og fremst er arbeidsgivers ansvar å sørge for et godt ytringsklima på arbeidsplassen. Et generelt inntrykk er imidlertid at det synes å være uklart for mange arbeidsgivere hvordan man faktisk skal legge til rette for varsling. Det har jeg full forståelse for.

Utarbeiding av varslingsrutiner reiser mange og kompliserte problemstillinger som ikke er løst i forarbeidene eller som ikke reguleres av arbeidsmiljøloven. Jeg har derfor tatt utgangspunkt $\mathrm{i}$ en tenkt situasjon, hvor en arbeidsgiver skal avklare hva han må eller $b \phi r$ gjøre for å legge til rette for varsling. Dernest, ved avslutningsvis å peke på svakheter ved lovteksten, håper jeg oppgaven kan være et innlegg i debatten om fremtiden til varslingsreglene.

\subsection{Hva varsling er}

\subsubsection{Innledning}

Temaet for oppgaven er tilrettelegging for varsling. Det må derfor sies noe om hva begrepet varsling innebærer. I det følgende presenteres først lovgivers forutsetninger om betydningen av varsling, herunder hva som menes med kritikkverdige forhold. Deretter en nærmere redegjørelse for hva varslingsfenomenet er, herunder hvordan det reguleres $\mathrm{i}$ norsk og utenlandsk rett, og hvem det skal legges til rette for varsling for. Tilslutt

\footnotetext{
${ }^{2}$ Møte i Odelstinget torsdag 16. november 2006 kl. 13.
} 
redegjøres det for forskjellen mellom lovbestemt varslingsplikt og varslingsbegrepet slik det skal forstås i arbeidsmiljølovens forstand.

\subsubsection{Lovgivers forutsetninger}

Hvis fenomenet varsling, ut fra et samfunnsperspektiv, verken hadde verdi eller betydning, ville varsling neppe blitt et tema for lovgiver ${ }^{3}$, og arbeidsgiver blitt pålagt en plikt til å legge til rette for varsling. Hele varslingsinstituttet hviler derfor på en grunnleggende erkjennelse av at varsling kan være et gode både for arbeidsmiljøet, virksomheten og samfunnet for $\emptyset v$ rig.

Under odelstingsdebatten i 2006 ble det uttalt at ansattes varsling er "vår viktigste kilde $i$ kampen mot korrupsjon, miljøkriminalitet, omsorgssvikt $i$ våre institusjoner eller pasientbehandling $i$ strid med etiske standarder" 4 . Med dette menes at ansattes varsling gir en mulighet til å avdekke og forebygge kritikkverdige forhold på arbeidsplassen. I tillegg til de eksemplene som ble nevnt, kan varsling også bidra til å avdekke kritikkverdige forhold som blant annet mobbing, seksuell trakassering, diskriminering, rusmisbruk, farlige produkter og forhold på arbeidsplassen som utgjør en fare for personers liv og helse. Listen kan gjøres meget lang. Begrepet kritikkverdige forhold omfatter alle straffesanksjonerte forhold, brudd på lovbestemte forbud og påbud, brudd på etiske normer med allmenn oppslutning eller brudd på virksomhetens etiske retningslinjer ${ }^{5}$.

Varsling som virkemiddel i bekjempelsen av $\emptyset$ konomisk kriminalitet blir i saerlig grad fremhevet i forarbeidene ${ }^{6}$. Slik kriminalitet foregår i det skjulte, og vil derfor i mange

\footnotetext{
${ }^{3}$ At varslingsreglene først nå er blitt lovfestet, skyldes nok først og fremst $\emptyset \mathrm{kt}$ bevissthet rundt betydningen av varsling.

${ }^{4}$ Odelstingsdebatten torsdag 16. november 2006 kl. 13, ordfører for saken Dagfinn Sundsbø (SP).

${ }^{5}$ Ot.prp.nr.84 (2005-2006) side 37. Når det gjelder brudd på virksomhetens etiske retningslinjer, uttales det på side 50 at det må "vare tale om rutiner som er tydelig uttalte og som er nedfelt i skriftlige dokumenter som er gjort kjent for ansatte og ledelse”.

${ }^{6}$ Se for eksempel Ot.prp.nr.84 (2005-2006) side 33
} 
tilfeller ikke bli avslørt uten at noen varsler. Finansskandalene i de amerikanske selskapene Enron og WorldCom (henholdsvis 2001 og 2002), som førte til at selskapene gikk konkurs, ble avslørt ved at ansatte varslet ${ }^{7}$. Her hjemme ble Siemens-saken, som dreide seg om overfaktureringer av Forsvaret på mer en 60 millioner kroner av Forsvaret, avslørt ved at en ansatt varslet ${ }^{8}$. Betydningen av at det varsles om slik kriminalitet ligger i at den $i$ scerlig grad har en samfunnsskadelig karakter. I Riksrevisjonens rapport for 2008/2009 oppsummeres den samfunnsskadelige betydningen av $\varnothing$ konomisk kriminalitet ${ }^{9}$ :

"Økonomisk kriminalitet fører til vesentlige omkostninger for samfunnet. Det antas at skatter og avgifter som unndras fellesskapet, utgjør titalls milliarder kroner hvert år. I tillegg kommer omkostninger og effektivitetstap i form av blant annet konkurransevridninger og tyverier fra forbrukere, investorer og naringslivet generelt. Økonomisk kriminalitet virker også nedbrytende på samfunnsmoralen og svekker grunnlaget for velferdsstaten. Bekjempelse av фkonomisk kriminalitet har derfor vart og er et prioritert område for myndighetene."

\subsubsection{Nærmere om varslingsfenomenet}

Frihet til å ytre seg er en grunnleggende rettighet som er nedfelt i Grunnloven $§ 100 \mathrm{og}$ EMK artikkel $10 \mathrm{nr} 1$. Ytringsfriheten omfatter både menings- og faktaytringer. En type ytring er deltakelse i politisk eller faglig debatt. En annen og sarlig type ytring er varsling om kritikkverdige forhold på arbeidsplassen.

Ved at reglene om varsling er plassert i arbeidsmiljøloven, er begrepet varsling i betydningen "whistleblowing" regulert som et arbeidsrettslig fenomen i Norge. I aml § 2-4 (1) fremgår at arbeidstakerne har "rett til å varsle om kritikkverdige forhold $i$

\footnotetext{
${ }^{7}$ http://www.time.com/time/subscriber/personoftheyear/2002/poyintro.html

${ }^{8}$ Monsen, Per-Yngve Muldvarp i Siemens, Oslo (2008)

${ }^{9}$ Riksrevisjonens unders $\phi$ kelse av myndighetenes innsats mot фkonomisk kriminalitet, dokument nr. 3:3 (2008-2009), side 96.

http://www.riksrevisjonen.no/Aktuelt/Pressemeldinger/Pressemelding_Dok 3 _3_2008_2009.htm
} 
virksomheten", og dette forutsetter at varsleren er en arbeidstaker.

Gjengjeldelsesreaksjoner mot arbeidstaker som varsler i samsvar med aml § 2-4 "er forbudt" jf. aml § 2-5. Og plikten i aml § 3-6 om å legge til rette for varsling retter seg mot arbeidstakernes varsling. En definisjon på hvem varsleren er, gis av forfatterne Marit Skivenes og Sissel C. Trygstad i boka "Varslere. Om arbeidstakere som sier ifra!":

”En varsler er (...) en arbeidstaker som sier ifra om kritikkverdige forhold på arbeidsplassen til en person eller instans (internt eller eksternt) som har myndighet til å gjøre noe med problemet". 10

Varsling i betydningen "whistleblowing" er imidlertid verken et nytt eller et særnorsk fenomen, og når det gjelder $h v a$ varsling er, finnes det ingen universell og omforent definisjon. De fleste lands regulering av varslingsfenomenet tar imidlertid, i likhet med Norge, utgangspunkt $\mathrm{i}$ at varsling er arbeidsrelatert. Derav er det de ansattes adgang til å varsle som reguleres. Som eksempler kan nevnes Storbritannias "The Public Interest Disclosure Act (PIDA)" fra 1998 som gjelder både private og offentlig ansatte, Sveriges "Tryckfrihetsförordningen" fra 1949 og "Yttrandefrihetsgrundlagen" fra 1991 som kun gjelder offentlige ansatte, USAs "The Whistleblower Protection Act" fra 1989 som kun gjelder offentlig ansatte og New Zealands "Protected Disclosures Act 2000" som også kun gjelder offentlig ansatte.

Staten South Australia i Australia har en lov som utgjør et unntak; "Corporations Act 2001", som i kapittel 9 har bestemmelser om "protection for whistleblowers" ${ }^{11}$. I del 9.4AAA paragraf (section) 1317 AA fremgår det hvem som omfattes av lovens anvendelsesområde når det gjelder "whistleblowers" ${ }^{12}$. I tillegg til ansatte og lokale "officers" i australske selskap, omfattes også underleverandører til slike selskap og disse underleverandørenes ansatte. De sistnevnte blir å anse som en tredjepart i den

\footnotetext{
${ }^{10}$ Skivenes, Marit (2007) side 17.

${ }^{11}$ Det kan selvsagt være flere unntak. Meg bekjent finnes det ikke noe tilsvarende i europeisk lovgivning.

${ }^{12}$ http://www.austlii.edu.au/au/legis/cth/consol_act/ca2001172/s1317aa.html
} 
arbeidsrettslige sammenhengen ${ }^{13}$. Dette illustrerer at varsling som fenomen ikke er avgrenset til arbeidssituasjonen. Dette skal jeg i det følgende forklare nærmere.

Uavhengig av rettslig plassering, er den helt primære funksjonen ved varsling at det er et virkemiddel for å avdekke kritikkverdige forhold. Varsling som virkemiddel er derfor like egnet enten varsleren er en arbeidstaker eller en tredjepart. Et illustrerende eksempel er at vannverksskandalen ved Nedre Romerike Vannverk startet ved at en leverandør til vannverket sendte en e-post til Aftenposten om mulige misligheter ${ }^{14}$.

Oslo kommune og Utenriksdepartementet er eksempler på virksomheter som har sett nytteverdien av varsling $\mathrm{i}$ et slikt perspektiv, og de har derfor åpnet varslingstjenesten sin også for andre enn ansatte ${ }^{15}$. På Oslo kommunes nettsider fremgår det at "alle som ønsker det kan varsle, for eksempel privatpersoner, brukere av kommunens tjenester, leverandфrer, organiasjoner [sic!] og kommunens egne ansatte." 16

Utenriksdepartementets varslingsplakat sier at "[e]ksterne personer uten tilknytning til utenrikstjenesten er også velkomne til å varsle om ethvert kritikkverdig forhold. For slike varslere gjelder retningslinjene så langt de passer." ${ }^{~} 17$ Utenfor den arbeidsrettslige terminologien bruker man altså begrepet "varsler" om enhver person som sier fra om kritikkverdige forhold i en virksomhet.

Den arbeidsrettslige definisjonen av varsleren som arbeidstaker, må derfor sies å dekke kun en $d e l$ av varslingsfenomenet. Forarbeidene til arbeidsmiljøloven har imidlertid ikke foretatt nærmere overveielser av nytten og betydningen av varsling ut over de

\footnotetext{
${ }^{13}$ Andre eksempler på tredjepart kan for eksempel være en kunde av en privat bedrift, revisor overfor et foretak, klient hos et advokatfirma eller en pårørende til en sykehjemspasient.

${ }^{14}$ Gedde-Dahl, Siri (2008) side 187

${ }^{15} \mathrm{Se}$ http://www.regjeringen.no/nb/dep/ud/tema/Folkerett/Antikorrupsjon/varslingstjenesten.html?id=495009 og http://www.oslo.kommune.no/varsling

${ }^{16}$ http://www.oslo.kommune.no/category.php?categoryID=27004

${ }^{17}$ Utenriksdepartementets varslingsplakat kan lastes ned fra http://www.regjeringen.no/nb/dep/ud/tema/Folkerett/Antikorrupsjon/varslingstjenesten.html?id=495009
} 
arbeidsrettslige konstellasjoner. Jeg kan heller ikke se at dette er drøftet i det фvrige rettskildematerialet. Ut fra dette må det kunne konkluderes med at man bruker begrepet varsling også om varsling fra tredjepart, men at dette altså ikke er en rettslig definisjon i betydningen varsling/"whistleblowing" i arbeidsmiljølovens forstand.

Fordi plikten til å legge til rette for varsling kun retter seg mot de ansatte, er det innenfor denne rammen plikten behandles i kapittel 3. Ut fra det jeg har redegjort for over, er det imidlertid gode grunner for at arbeidsgiver også bør legge til rette for varsling fra tredjepart. Dette behandles i kapittel 4 om hva arbeidsgiver $b \phi r$ gjøre.

Varslingsreglene regulerer også arbeidstakernes adgang til å varsle når varslingsplikt ikke er lovfestet. Dette understrekes av flertallet i Arbeids- og sosialkomiteen på side $9 \mathrm{i}$ Innst.O.nr.6 (2006-2007). Lovfestet varslingsplikt for arbeidstakere er regulert flere steder i lovgivningen, og i arbeidsmiljøloven § 2-3 fremgår det blant annet at arbeidstakerne har plikt til å varsle om trakassering og diskriminering på arbeidsplassen. Når arbeidstakeres varslingsplikt er lovfestet, fremgår hjemmelen for varsling av egne bestemmelser om dette, og altså ikke av aml § 2-4. Ulovfestet varslingsplikt kan fremgå av for eksempel instruks eller reglementer om avviksrapportering, og det er denne varslingsplikten som omfattes av varslingsreglene. Dette må innebære at varslingsbegrepet, slik det brukes i aml § 3-6, også må forstås innenfor denne rammen ${ }^{18}$.

\footnotetext{
${ }^{18} \mathrm{Aml}$ § 3-6 gir altså ikke hjemmel til å pålegge arbeidsgiver å legge til rette for varsling i samsvar med lovfestet varslingsplikt. En slik hjemmel kan kanskje utledes av eksempelvis aml § 2-3, hvis bestemmelse kanskje kan gjøre det nødvendig å utarbeide rutiner for at varslingsplikten skal kunne overholdes av arbeidstakerne. Eventuelt kan kanskje en slik hjemmel utledes av internkontrollreglene. Ut fra en slik tankegang kan plikten i praksis oppfylles ved en samkjøring med aml § 3-6 for de virksomhetene som omfattes av aml § 3-6. Men aml § 3-6 omfatter ikke alle. Motsatt blir det med en plikt som kan utledes av aml $\S 2-3$; den omfatter alle virksomheter.
} 


\subsection{Begrepsavklaringer}

\subsubsection{Innledning}

I det følgende presenteres noen ytterligere begreper som er sentrale å avklare i relasjon til aml § 3-6; arbeidstaker, arbeidsgiver og hva som menes med varslingsrutiner eller andre tiltak. Det nærmere innholdet i aml § 3-6 redegjøres det for i kapittel 3.

\subsubsection{Arbeidstakerbegrepet}

Med arbeidstaker menes i følge aml § 1-8 (1) "enhver som utfører arbeid $i$ annens tjeneste”. Aml § 3-6 ilegger en plikt til å legge til rette for at arbeidstakerne kan varsle. Arbeidstakerbegrepet må avgrenses mot de tilfeller hvor den som påtar seg et arbeid utfører dette for egen regning og risiko, som eksempel kan nevnes selvstendige næringsdrivende og konsulenter. I tvilstilfeller må den nærmere grensedragningen vurderes konkret.

\subsubsection{Arbeidsgiverbegrepet}

Arbeidsgiver defineres i aml § 1-8 (2) som "enhver som har ansatt arbeidstaker for å utføre arbeid i sin tjeneste". Arbeidsgiver har det overordnede ansvaret for at bestemmelsene gitt i og i medhold av arbeidsmiljøloven blir overholdt jf. aml § 2-1. Aml § 3-6 pålegger uttrykkelig arbeidsgiver en plikt til å legge til rette for de ansattes varsling.

Arbeidsgiverbegrepet dekker både fysiske og juridiske personer som for eksempel aksjeselskap, andelslag, stiftelser, statsforetak og kommuner. For virksomheter i et konsern er hovedregelen at den enkelte virksomhet er arbeidsgiver for sine arbeidstakere ${ }^{19}$.

Arbeidsgiver er ansvarlig for arbeidsmiljøet $i$ den samlede virksomhet ${ }^{20}$. De bestemmelsene i loven som gjelder arbeidsgiver gjelder også "den som i arbeidsgivers sted

${ }^{19}$ Ot.prp.nr.49 (2004-2005) side 74 
leder virksomheten”. Dette innebærer at den som utøver eller har fått delegert arbeidsgiverfunksjoner på vegne av arbeidsgiveren er bundet av aml § 3-6 på samme måte som arbeidsgiver. Når arbeidsgiver er en juridisk person, vil arbeidsgiverfunksjonene utøves av den juridiske persons organer eller andre som kan opptre på dennes vegne ${ }^{21}$. I aksjeselskaper vil for eksempel arbeidsgiverfunksjoner utøves av både aksjeselskapets generalforsamling, bedriftsforsamling, styre og daglig leder ${ }^{22}$. Når det gjelder hva som er mest praktisk i henhold til aml § 3-6, må vel utgangspunktet være at det er den som utøver den reelle instruksjon og kontroll som først og fremst har ansvaret for å legge til rette for $\operatorname{varsling}^{23}$.

\subsubsection{Varslingsrutiner og andre tiltak}

Plikten i aml § 3-6 omfatter enten utarbeiding av "rutiner" for intern varsling eller å treffe "andre tiltak" som legger til rette for intern varsling. Med varslingsrutiner menes "prosedyrer for varsling og håndtering av kritiske ytringer $i$ virksomheten som er nedfelt $i$ reglementer, instrukser, avtaler, prosedyrer mv." 24.

Med "andre tiltak" menes mer enkeltstående informasjonstiltak om adgangen til å varsle, som eksempel ved regelmessige medarbeidersamtaler eller ved informasjonsmøter hvor man drøfter hvordan intern kritikk skal håndteres ${ }^{25}$.

Der hvor jeg sikter til både varslingsrutiner og andre tiltak vil jeg omtale dette som "varslingstiltak". Det nærmere innholdet i varslingstiltak behandles i kapittel 3.

\footnotetext{
${ }^{20}$ Jakhelln (2007) side 46

${ }^{21}$ Ot.prp.nr.49 (2004-2005) side 74

22 Jakhelln (2007) side 37

${ }^{23}$ Ibid. side 41

${ }^{24}$ Ot.prp.nr.84 (2005-2006) side 52

${ }^{25}$ Ibid. side 54
} 


\subsection{Avgrensning av oppgaven}

Formålet med oppgaven er å si noe om hva arbeidsgiver må eller $b \phi r$ gjøre for å legge til rette for varsling. Plikten til å legge til rette for varsling gjelder kun de ansattes varsling. Dette betyr at jeg i kapittel 3 om hva arbeidsgiver må gjøre, kun behandler tiltak for de ansatte. I kapittel 4 om hva arbeidsgiver $b \phi r$ gjøre, behandler jeg spørsmålet om arbeidsgiver bør legge til rette for varsling også fra tredjepart.

Rettslig sett blir tilrettelegging for varsling noe annet enn selve håndteringen av en varslingssituasjon. Tilrettelegging for varsling kommer i forkant av en varslingssituasjon. Spørsmålet om hvordan varselet skal håndteres aktiveres først når arbeidsgiver har mottatt eller er blitt kjent med et varsel. Problemstillinger knyttet til håndtering av varsel oppstår altså uavhengig av om det er tilrettelagt for varsling eller ikke. Forarbeidene har bevisst valgt å ikke omtale saksbehandlingsregler. I Ot.prp.nr.84 (2005-2006) på side 39 sies det for eksempel at "hvilke prosedyrer som skal følges i slike tilfeller, eventuelt må reguleres $i$ scerlovgivningen". Saksbehandlingsregler vil derfor kun behandles i den grad det er nødvendig for å si noe om hvordan det $m a ̊$ eller $b \phi r$ legges til rette for varsling. Som eksempel kan det nevnes at regler om innsynsrett blir et tema når det gjelder adgangen til å varsle anonymt ${ }^{26}$.

I følge aml § 1-2 (1) gjelder arbeidsmiljøloven som utgangspunkt alle virksomheter som sysselsetter arbeidstaker(e). Begrepet "virksomhet" er ikke definert i loven, men det er på det rene at virksomhetsbegrepet omfatter alle former for næringsvirksomhet, den offentlige forvaltning, ideell og immateriell virksomhet ${ }^{27}$. Plikten i aml § 3-6 retter seg mot "arbeidsgiver" og må i utgangspunktet gjelde for alle arbeidsgivere i virksomheter hvor det sysselsettes arbeidstakere ${ }^{28}$. Ut fra dette er har jeg ikke avgrenset behandlingen til noen spesiell virksomhetsform.

\footnotetext{
${ }^{26}$ Tilrettelegging for anonym varsling behandles i kapittel 4.

${ }^{27}$ Jakhelln (2007) side 45

${ }^{28}$ Forarbeidene trekker heller ikke et skille mellom ulike typer virksomheter når det gjelder aml § 3-6.
} 
Det er aml § 3-6 som er det rettslige utgangspunktet for oppgaven. Dette innebærer at det ikke vil foretas en inngående behandling av de øvrige varslingsreglene. Aml § 2-4 behandles i den utstrekning det er nødvendig for å si noe om hva varslingstiltak ikke kan gå ut på. Aml § 2-5, som nedsetter forbud mot at arbeidsgiver gjengjelder forsvarlig varsling, vil ikke bli behandlet ut over at eventuelle varslingsrutiner $b \phi r$ si noe om hvordan en ansatt som varsler vernes.

I kapittel 4 behandles hva arbeidsgiver $b \phi r$ gjøre, men det redegjøres ikke for ethvert tiltak arbeidsgiver kan gjøre. Når det gjelder hva arbeidsgiver kan gjøre, så er dette negativt avgrenset til hva arbeidsgiver ikke kan gjøre i utarbeidelsen av varslingstiltak. Dette behandles i kapittel 5.

\subsection{Metode og rettskildebilde}

\subsubsection{Innledning}

Oppgaven er hovedsakelig en fremstilling av gjeldende rett. Det benyttes en rettsdogmatisk metode i tråd med den tradisjonelle metodelæren. Fordi rettskildene dels gir grunnlag for motstridende slutninger, og fordi forarbeidene spesielt gir grunnlag for innbyrdes motstridende slutninger, blir harmoniserings-/vektspørsmålet gjennomgående aktuelt. For ikke å plage leseren med eksplisitte slutnings- og harmoniseringsspørsmål underveis, presenteres sammen med rettskildene hva som ligger til grunn for vurderingene.

Å gi et klart svar på hva som er gjeldende rett når det gjelder arbeidsgivers tilretteleggingsplikt byr imidlertid på utfordringer: For det første har varslingsreglene bare vært i kraft i underkant av to år, og det finnes ennå ingen rettspraksis rundt aml § 3-6. For det andre gis det lite veiledning i selve lovteksten. For det tredje er forarbeidene svært sparsomme med å konkretisere hva plikten går ut på; konkretiseringer kommer først og fremst som anbefalinger. For det fjerde er konkretiseringen omtrent ikke problematisert i juridisk litteratur. I den grad det er berørt, er det stort sett i samsvar med hva som fremgår av forarbeidene. 
Med dette som bakgrunn må rettskildematerialet, for at jeg skal kunne gi en fremstilling av gjeldende rett, suppleres med vurderinger av de formål og hensyn som kan utledes av forarbeidene. Fordi gjeldende rett per i dag er uklar, blir det ikke en ren de lege lata fremstilling. Det blir også til en viss grad en fremstilling de sententia ferenda, som er en betegnelse for den rettsoppfatning som anbefales lagt til grunn som gjeldende rett. I den grad jeg kommer med egne betraktninger under behandlingen av gjeldende rett gjør jeg dette klart. Mine egne betraktninger kommer først og fremst under behandlingen av varslingsreglene de lege ferenda i kapittel 6.

\subsubsection{Internasjonale rettskilder}

Internasjonale regler av relevans for retten til å varsle i arbeidslivet er artikkel 10 i Den europeiske menneskerettskonvensjonen (EMK) og artikkel 19 i FN-konvensjonen om sivile og politiske rettigheter $(\mathrm{SP})^{29}$. Fordi EMK og SP er inkorporert i norsk rett ved menneskerettsloven $\S 2$, har bestemmelsene i EMK og SP samme trinnhøyde og rettskildemessige vekt som norsk lov ${ }^{30}$. Norsk rett presumeres å være i overensstemmelse med disse ${ }^{31}$. EMK og SP har relevans for den generelle retten til å ytre seg, men noen nærmere veiledning om utarbeidelse av varslingsrutiner finner en ikke her.

USA har The Sarbanes Oxley-Act (SOX) fra 2002, som gjelder alle børsnoterte selskaper i USA. SOX pålegger disse selskapene å sette opp egne revisjonskomiteer, såkalte ”audit commitees”. Disse skal utarbeide rutiner for å sikre arbeidstakeres mulighet til å rapportere anonymt vedrørende tvilsom bokføring eller revisjonsmessige forhold. Ut over at

\footnotetext{
${ }^{29}$ Europarådets konvensjon om beskyttelse av menneskerettighetene og de grunnleggende friheter (EMK) av 4. november 1950. De forente nasjoners internasjonale konvensjon om sivile og politiske rettigheter av 16. desember 1966 (SP).

${ }^{30}$ Ved motstrid skal imidlertid bestemmelser i EMK og SP gå foran annen norsk lov jf. § 3 i lov om styrking av menneskerettighetenes stilling i norsk rett (menneskerettsloven) av 21. mai $1999 \mathrm{nr} 30$.

${ }^{31}$ Presumsjonsprinsippet innebærer i hovedsak at norske regler antas å være i overensstemmelse med våre folkerettslige forpliktelser, se for eksempel Finanger I-dommen i Rt-2000-1811.
} 
forarbeidene nevner SOX når det gjelder andre lands rett, brukes den ikke direkte i arbeidet med aml § 3-6.

Det kan også nevnes at New Zealands Protected Disclosures Act 2000 har en bestemmelse som pålegger offentlige arbeidsgivere en plikt til å utarbeide rutiner for varsling $^{32}$. Forarbeidene til arbeidsmiljøloven nevner imidlertid ikke denne loven.

\subsubsection{Norske rettskilder}

Grunnloven (Grl) står over formell lov i rang ${ }^{33}$. Dette innebærer at varslingstiltak ikke kan begrense de ansattes ytringsfrihet mer enn det som følger av Grl § 100 og aml § 2-4. Dette behandles nærmere i kapittel 5.

Arbeidsmiljøloven er hovedkilden og det rettslige utgangspunktet for oppgaven.

Aml § 3-6 ilegger en offentligrettslig plikt for arbeidsgiver, hvilket nok gjør plikten ufravikelig innenfor de rammer som følger av bestemmelsen. Plikten til å iverksette tiltak inntrer "såfremt forholdene $i$ virksomheten tilsier det" ${ }^{34}$. Når plikten inntrer, og det nærmere innholdet i denne, er ikke presisert. Veiledning om det nærmere innholdet må derfor søkes i det $\emptyset$ vrige rettskildematerialet, først og fremst forarbeidene. Det ligger imidlertid begrensinger på hvor langt man kan gå i å utpensle innholdet i plikten. Plikten er offentligrettslig, og kravet til hjemmel (legalitetsprinsippet), herunder hensynet til forutberegnelighet, gjør at jeg i tolkningen av bestemmelsen legger særlig vekt på ordlyden for å unngå en utvidende tolkning ${ }^{35}$.

\footnotetext{
${ }^{32}$ For generell informasjon om loven, se http://www.justice.govt.nz/bribery-corruption/chapter-8.html. Selve loven ligger her: http://www.ombudsmen.parliament.nz/internal.asp?cat=100099. Plikten i paragraf (section) 11 oppstiller konkrete minstekrav. Se mer om dette i kapittel 6.

${ }^{33}$ Kongeriget Norges Grundlov, given i Rigsforsamlingen paa Eidsvold den 17de Mai 1814 (Grunnloven)

${ }^{34}$ Innholdet i plikten behandles i kapittel 3.

${ }^{35}$ Legalitetsprinsippet innebærer at ethvert inngrep i private rettssubjekters rettsstilling er betinget av en foreliggende kompetanse. Prinsippet er først og fremst begrunnet i rettssikkerhetshensyn, da private ikke skal utsettes for inngrep som de ikke kan forutse.
} 
Personopplysningslovens (popplyl) formål er å beskytte den enkelte mot at personvernet blir krenket gjennom behandling av personopplysninger jf. popplyl $\S 1$ (1) ${ }^{36}$. Personopplysingsloven er en generell lov som gjelder så langt ikke annet følger særskilt av lov jf. popplyl § 5. Da arbeidsmiljøloven ikke har særskilte bestemmelser om hvordan personvernet skal ivaretas i forbindelse med varsling, blir personopplysningsloven den primære rettskilden når det gjelder varslingsrutiner og forholdet til personvernet.

Personopplysningsforskriften er gitt med hjemmel i personopplysningsloven ${ }^{37}$. Selv om forskrifter generelt har lavere vekt enn lov, inneholder forskriften en rekke bestemmelser som på viktige punkter supplerer eller modifiserer personopplysningslovens bestemmelser 38

Forarbeidene til arbeidsmiljøloven blir, i tillegg selve loven, den viktigste rettskilden. Fordi aml § 3-6 i seg selv gir lite veiledning, må forarbeidene til bestemmelsen få stor vekt siden lovgivers vilje fremgår her ${ }^{39}$.

Juridisk teori har i liten grad behandlet aml § 3-6, og i den grad det er behandlet er det stort sett $\mathrm{i}$ form av gjengivelser av forarbeidene eller henvisninger til Arbeidstilsynets varslingsveileder. Det er først og fremst de øvrige varslingsreglene aml §§ 2-4 og 2-5 som har vært gjenstand for problematisering.

\footnotetext{
${ }^{36}$ Lov om behandling av personopplysninger (personopplysningsloven) av 14. april $2000 \mathrm{nr} 31$

${ }^{37}$ Forskrift om behandling av personopplysninger (personopplysningsforskriften) av 15. desember $2000 \mathrm{nr}$ 1265 .

${ }^{38}$ At forskrifter generelt har lavere rang enn lov følger av lex superior-prinsippet. Om personopplysningsforskriften, se www.rettsdata.no Kommentarer til personopplysningsloven, Dag Wiese Schartum, note $(*)$.

${ }^{39}$ Eckhoff legger til grunn at "meget tyder(...) på” på at forarbeidene blir utslagsgivende når lovteksten er vag og flertydig. Eckhoff (2000) side 79.
} 
Arbeidstilsynet er et forvaltningsorgan underlagt Arbeids- og inkluderingsdepartementet, og fører tilsyn med at virksomhetene overholder arbeidsmiljølovens krav. Arbeidstilsynet har utgitt en veileder om varslingsreglene hvor det gis råd om virksomhetenes tilrettelegging for varsling ${ }^{40}$. At Arbeidstilsynet er et forvaltningsorgan med sarlig kompetanse i arbeidsmiljøloven må få betydning for den rettskildemessige vekten.

Når det gjelder aml § 3-6, kan Arbeidstilsynet, ved pålegg eller andre enkeltvedtak, overprøve arbeidsgivers vurdering av om det er behov for varslingstiltak jf. aml § 18-6. Arbeidstilsynets enkeltvedtak må ha samme rettskildemessige vekt som enkeltvedtak fra andre forvaltningsorganer. Arbeidstilsynets adgang til å overprøve arbeidsgivers vurderinger må sies å høre inn under forvaltningens frie skjønn, og ved domstolsprøving blir forvaltningens skjønnsutøvelse kun satt til side hvis den er vilkårlig eller sterkt urimelig ${ }^{41}$. Av denne grunn kan det være relevant å se på hvordan Arbeidstilsynet har reagert i forhold til sin veiledningsplikt. Arbeidstilsynet har til nå utført en del tilsyn med overholdelsen av aml § 3-6, og resultatene fra disse viser hvordan tilsynet så langt fortolker aml § 3-6. Fordi praksisen er ny og vil kunne endre seg, må dette få betydning for den rettskildemessige vekten. Resultatene behandles i kapittel 3.

Datatilsynet er et forvaltningsorgan underordnet Justisdepartementet, og har tilsyns- og veiledningskompetanse når det gjelder personopplysningslovens bestemmelser. Personopplysningsloven medfører krav til både utarbeidelsen og praktiseringen av et varslingssystem etter aml § 3-6. Datatilsynets varslingsveileder gir veiledning om hvilke krav personopplysningsloven stiller til et varslingssystem ${ }^{42}$. Datatilsynet har, i likhet med Arbeidstilsynet, særlig kompetanse på det rettsområdet det er satt til å overvåke. Den rettskildemessige statusen til Datatilsynets rådgivende uttalelser og vedtak blir derfor å vurdere på samme måte som for Arbeidstilsynet. Datatilsynet har til nå kun utført noen få

\footnotetext{
${ }^{40}$ Arbeidstilsynets varslingsveileder på www.arbeidstilsynet.no

${ }^{41}$ Se for eksempel Rt-1956-1319

${ }^{42}$ Varslingsveilederen Varsling $i$ arbeidslivet ("whistle-blowing") av 10. mars 2007 er en artikkel av seniorrådgiver Astrid Flesland i Datatilsynet og ligger på nettsidene til Datatilsynet www.datatilsynet.no
} 
tilsyn med virksomheters varslingsrutiner, men resultatene er per i dag ennå ikke tilgjengelige ${ }^{43}$.

Virksomhetenes praktisering av aml § 3-6 må som utgangspunkt ha lav rettskildemessig vekt, og det er for tidlig å si om praksis har dannet sedvanerett på området. I tillegg finner en få virksomheter som hittil har fulgt opp plikten. I oppgaven brukes derfor virksomhetenes praksis kun som eksempler på hvordan det kan eller $b \phi r$ gjøres. Av de virksomhetene som har utarbeidet varslingsrutiner er det særlig i offentlig sektor man finner eksempler. Som eksempler kan nevnes Oslo kommune og Utenriksdepartementet.

Reelle hensyn, her i betydningen de grunnleggende hensyn bak varslingsreglene generelt og de konkrete hensyn bak aml § 3-6 spesielt, får stor betydning. Som utgangspunkt ligger det begrensninger i bruken av reelle hensyn ved fastleggingen av gjeldende rett. Bruken må være lojal mot lovgiver, og på legalitetsprinsippets område har reelle hensyn begrenset vekt jf. legalitetsprinsippet som er nevnt ovenfor. Fordi hensyn og formål i stor grad kan utledes direkte fra forarbeidene, bør de imidlertid tillegges $\varnothing \mathrm{kt}$ vekt fordi de uttrykker lovgivers vilje.

\subsection{Den videre fremstillingen}

I kapittel 2 redegjør jeg for generelle hensyn og formål bak ytringsfriheten og varslingsreglene. I kapittel 3 gjør jeg rede for de minstekrav som må sies å følge av aml § 3-6 og personopplysningsloven. I kapittel 4 gjør jeg rede for hva arbeidsgiver bør gjøre når det skal legges til rette for varsling. I kapittel 5 angir jeg grensene for hva varslingsrutiner kan gå ut på. I kapittel 6 kommer de lege ferenda-betraktninger. I kapittel 7 kommer etterord.

\footnotetext{
${ }^{43}$ De var ikke tilgjengelige per 20. november 2008
} 


\section{Generelle hensyn bak varslingsreglene}

\subsection{Om ytringsfriheten generelt}

Fordi det overordnede hensynet bak varslingsreglene er å styrke ansattes ytringsfrihet, er det grunn til å si noe om ytringsfriheten som grunnleggende hensyn bak varslingsreglene.

Den generelle bestemmelsen om ytringsfriheten finner man i Grunnloven $\S 100$, hvor første ledd fastslår at "Ytringsfrihed bør finde sted". De tre hovedbegrunnelsene for ytringsfriheten ligger i sannhetsprinsippet, demokratiprinsippet og prinsippet om individets frie meningsdannelse med røtter i opplysningstiden. Prinsippene gir et "universelt forsvar" for ytringsfriheten, mens andre argumenter for ytringsfrihet vil være mer situasjonsbetinget ${ }^{44}$. Det fremgår av forarbeidene at det under utarbeidelsen av varslingsreglene er lagt "stor vekt" på disse prinsippene ${ }^{45}$.

For arbeidsgiver handler det om å forstå verdien av et åpent ytringsklima, og av at den enkelte fortsetter å være et fritt tenkende individ også i rollen som ansatt ${ }^{46}$. Ytringsfriheten er en grunnleggende menneskerett, mens arbeidsgivers krav på lojalitet ikke har samme status. I stedet for å sanksjonere kritikk, skal man se på kritikk som en mulighet til forbedring som kommer både ytringsklima, virksomhet og samfunn til gode. En arbeidsgiver som skal legge til rette for varsling bør derfor vite hvilke grunnleggende hensyn som ligger bak varslingsreglene.

Sannhetsprinsippet har utgangspunkt $\mathrm{i}$ at sannheten nås gjennom en prosess som er verdslig, kulturuavhengig og som skjer gjennom dialog. Sannhet nås best gjennom en fri meningsutveksling der fremsatte påstander korrigeres i konfrontasjon med andres meninger. Ved å høre motargumenter, kan en få bedre innsikt. Kontradiksjonsprinsippet i

\footnotetext{
${ }^{44}$ NOU 1999:27 side 5.

${ }^{45}$ Ot.prp.nr.84 (2005-2006) side 33.

${ }^{46}$ Justisdepartementet i St.meld.nr.26 (2003-2004) side 110 om avveiningsnormen mellom Grunnloven § 100

(2) og (3) og de begrensninger som kan legges i ytringsfriheten.
} 
norsk rett er et utslag av sannhetsprinsippet, som også har en parallell i det amerikanske uttrykket "The Marketplace of Ideas". Dette handler nettopp om at ideer og meninger skal kunne bringes frem og konkurrere i et "fritt marked". Ytringsfrihet er da en absolutt forutsetning.

Demokratiprinsippet medfører at det må være offentlighet rundt viktige samfunnsprosesser, og at det forut for valg og viktige beslutninger må kunne finne sted en fri meningsutveksling. Ytringsfrihet er derfor en grunnstein i demokratiet. Dette har en parallell i bedriftsdemokratiet på arbeidsplassen, ved at de ansatte skal tas med og få øve innflytelse på viktige beslutninger.

Prinsippet om individets frie meningsdannelse kalles også autonomiprinsippet. Prinsippet innebærer at "det myndige menneske” får sin personlige utvikling ved sosialisering og fri meningsutveksling med andre. Begrensninger i den enkeltes rett til å utvikle seg selv ved å bruke ytringsfriheten, kan bare begrunnes med andre enkeltindividers rett til en tilsvarende frihet.

\subsection{Formål og hensyn bak varslingsreglene spesielt}

\subsubsection{Klarlegging av rettstilstanden}

I 1999 avga Ytringsfrihetskommisjonen sin innstilling NOU 1999:27 Ytringsfrihed bør finde Sted med forslag til ny Grunnlov $§ 100$ om ytringsfrihet. Det ble ikke fremmet særlige regler om ansattes ytringsfrihet. Kommisjonen uttalte imidlertid at "[k]onflikten mellom ytringsfrihet og den ansattes lojalitetsplikt er av stor praktisk betydning: Rundt halvparten av Norges befolkning er $i$ en eller annen sammenheng ansatt hos andre." Kommisjonen fant derfor at det av denne grunn var "utilfredsstillende" at reglene som regulerer ansattes ytringsfrihet i så stor grad var ulovfestet og "delvis underutviklet." 47 Kommisjonen anbefalte et lovgivningsinitiativ som burde omfatte en "ncermere

\footnotetext{
${ }^{47}$ NOU 1999:27 side 171
} 
avklaring/definisjon av begrepet illojalitet, [og] at fenomenet «whistle blowing» lovreguleres " 48 . Dette markerte starten på et lovarbeid med det formål å klarlegge rettstilstanden for ansattes ytringsfrihet.

\subsubsection{Styrking av de ansattes ytringsfrihet}

Andre formål er "å styrke den reelle ytringsfriheten i ansettelsesforhold", og å fremme "åpenhet og bidra til et bedre ytringsklima i den enkelte virksomhet" ${ }^{49}$. Lovfestingen av aml § 2-4 "skal gi tydelige signaler om retten til à varsle" ${ }^{50}$. Dette retter seg først og fremst mot virksomhetene. Aml § 2-5 (2), som oppstiller et forbud mot gjengjeldelsesreaksjoner mot varsling i samsvar med aml $§ 2-4$, er i og for seg en understreking av varslingsretten ${ }^{51}$. Bestemmelsen må sees i forbindelse med departementet uttalelse om at " [e]n faktor som ser ut til å begrense mulighetene for å varsle er de ansattes frykt for gjengjeldelse fra arbeidsgiver, ledelse eller kolleger" 52.

Plikten i aml § 3-6 til å legge til rette for varsling er det viktigste virkemiddelet for å styrke den reelle ytringsfriheten på arbeidsplassene. Bestemmelsen må sees i sammenheng med at problemer med faktiske og uformelle begrensninger i adgangen til å varsle synes å ligge i selve arbeidsplassene.

\subsubsection{Virkemiddel for å avdekke og forebygge kritikkverdige forhold}

Innledningsvis er nevnt at varsling er et virkemiddel for å avdekke og forebygge kritikkverdige forhold på arbeidsplassen. Varslingsreglene skal bidra til å styrke varsling

\footnotetext{
${ }^{48}$ Ibid side 176

${ }^{49}$ Innst.O.nr.6 (2006-2007) side 1

${ }^{50}$ Ibid side 1.

52 Ot.prp.nr.84 (2005-2006) side 33. På side 43, under behandlingen av bestemmelsen, ble det uttalt at forbudet skal verne mot gjengjeldelser i vid forstand og at "[e]nhver ugunstig behandling som er en reaksjon på ytringen bør dermed i utgangspunktet regnes som gjengjeldelse”.
} 
som et slikt virkemiddel. Arbeidstakerne har gjerne førstehånds kjennskap til kritikkverdige forhold i virksomheten og kan derfor bidra til tidlig avdekking, med tilhørende redusert skadeomfang. I forarbeidene legges det sarlig vekt på at offentlige ansatte, ved en rett til frie ytringer, kan bidra til bedre kontroll med offentlige ytelser og ressursbruk.

\section{Hva må arbeidsgiver gjøre?}

\subsection{Kravene etter aml § 3-6}

\subsubsection{Innledning}

Spørsmålet er hva arbeidsgiver rent faktisk må foreta seg som et minstekrav for å tilfredsstille kravet i aml § 3-6. For arbeidsgivere som allerede mener å ha rutiner for varsling fra før ikrafttredelsen av aml § 3-6, blir spørsmålet hva de evt. ytterligere må foreta seg.

\subsubsection{Formål og hensyn bak aml § 3-6}

\subsubsection{Innledning}

Arbeids- og sosialkomiteen fastslo i Innst.O.nr.6 (2006-2007) at det "må vaere arbeidsgivers ansvar å sørge for et godt ytringsklima i virksomheten" ${ }^{53}$. Aml § 3-6 understreker dette, ved at arbeidsgiver pålegges en plikt til å vurdere behovet for, og eventuelt utarbeide, rutiner for varsling. Under departementets vurderinger i Ot.prp.nr.84 (2005-2006) s. 46 gis det uttrykk for de lovgivningspolitiske målsettingene bak aml § 3-6. Disse er helt sentrale for at arbeidsgiver skal forstå hensikten med det arbeidet som skal gjøres. I tillegg gir de veiledning om hvordan aml § 3-6 skal fortolkes.

\footnotetext{
${ }^{53}$ Innst.O.nr.6 (2006-2007) side 2
} 


\subsubsection{2 Økt bevissthet rundt ytringsfrihetsspørsmål}

En generell plikt til å vurdere tiltak, og en nærmere bestemt plikt til å iverksette tiltak for varsling, skal bidra til at arbeidsgiver får en $\varnothing \mathrm{kt}$ bevissthet rundt ytringsfrihetsspørsmål for de ansatte. Det skal også bidra til at arbeidsgiver får bedre forståelse for at et godt ytringsklima er et gode for virksomheten, og at varsling er en del av de problemstillingene som knytter seg til det øvrige arbeidet med helse-, miljø- og sikkerhet (HMS).

Varslingstiltak skal gi ansatte signal om at virksomheten tar ytringsfrihet på alvor.

\subsubsection{Bidrag til et godt ytringsklima}

I forarbeidene legges til grunn at et "åpent ytringsklima og gode reelle muligheter for å si fra om kritikkverdige forhold er et vesentlig trekk ved et godt arbeidsmiljø og en sunn bedriftskultur" ${ }^{4}$. I Arbeidstilsynets varslingsveileder sies at "[i] et godt arbeidsmiljø er det en lav terskel for å si fra om kritikkverdige forhold på arbeidsplassen" " 55 . Tiltak for å styrke ytringsklimaet skal inngå som integrert del av det etablerte HMS-arbeidet. Å ytre seg kritisk om forhold i virksomheten skal ikke være noe ekstraordinært, men tvert i mot en del av den alminnelige samarbeids- og kommunikasjonskulturen. Idealet om et godt arbeidsmiljø innebærer at ytringsklimaet er slik at konfliktfylte varslingssituasjoner ikke oppstår. Arbeidstilsynet legger til grunn at "dersom kritikkverdige forhold problematiseres eller avdekkes, må det fokuseres på saken og ikke den som sier fra" ${ }^{56}$. Målet om et godt ytringsklima er kanskje det viktigste hensynet bak aml § 3-6.

\subsubsection{Forebygging}

Klare og kommuniserte varslingsrutiner kan gi de ansatte bevissthet rundt hvordan og hvorfor det skal varsles, og slik forhindre at det danner seg ukulturer eller at grunnløse mistanker og påstander får grobunn og slik skape et dårlig arbeidsmiljø. Hvis alle i

\footnotetext{
${ }^{54}$ Ot.prp.nr.84 (2005-2006) side 46

${ }^{55}$ Arbeidstilsynets varslingsveileder side 4

${ }^{56}$ Arbeidstilsynets varslingsveileder side 15
} 
virksomheten, inkludert arbeidsgiver, vet at det både er enkelt og akseptert å varsle, vil dette i seg selv kunne tilføre en kontrollfunksjon. Særlig preventivt kan det kanskje virke mot $\emptyset$ konomisk kriminalitet, da den relativt lave oppdagelsesrisikoen nettopp er et forhold som fremmer slik kriminalitet ${ }^{57}$.

Hvis det er liten bevissthet rundt betydningen av varsling og i tillegg aksept for at det ikke sies ifra - "slik gjør vi det her hos oss" - vil dette kunne ha store skadevirkninger både for virksomhet, arbeidsmiljø og samfunn. Vannverksskandalen ved Nedre Romerike Vannverk viser et eksempel på hvordan det kan gå. Her hadde daglig leder, med samarbeidspartnere, gjennom flere år tappet de to interkommunale selskapene Nedre Romerike Vannverk og RA-2 for over 60 millioner kroner ${ }^{58}$. I granskningsrapporten ble det rettet kritikk mot styret for at det ikke var etablert varslingskanaler:

"Det har skjedd en rekke kritikkverdige forhold i selskapene som de ansatte i ulik grad har vart kjent med, men som styret hevder var ukjente for dem. Etter granskingsgruppens oppfatning kan styrene kritiseres for ikke å ha sфrget for kommunikasjonskanaler til de ansatte. Siden de ansatte ikke var representerte i styrene, ville slike kommunikasjonskanaler vart viktige for å få informasjon om hva som faktisk rørte seg $i$ selskapene." 59

\footnotetext{
${ }^{57}$ Utsagnet om at oppdagelsesrisikoen er "relativt" lav har jeg hentet fra side 4 i ØKOKRIM sin trendrapport 2008 på www.okokrim.no

${ }^{58}$ I granskningsrapporten av 30. mai 2007 av Nedre Romerike Distriktsrevisjon kom det frem at tappingen av vannverket etter alt å dømme startet allerede på 1970-tallet. Rapporten ligger her:

http://www.nrvra2.no/filarkiv/File/Granskningsrapport_NRV_RA2.pdf. Daglig leder Ivar T. Henriksen ble 14. februar 2008 dømt av Nedre Romerike tingrett. Den 7. september 2009 starter Eidsivating lagmannsrett ankebehandlingen.

${ }^{59}$ Sitatet er hentet fra sammendraget.
} 


\subsubsection{Styrke varsling som virkemiddel for avdekking av kritikkverdige forhold} Varsling er, som jeg allerede har påpekt, et virkemiddel for å få avdekket kritikkverdige forhold. Ved at det skal legges til rette for varsling vil varslingstiltak ytterligere styrke varsling som et slikt virkemiddel ${ }^{60}$.

\subsubsection{Lavere terskel for varsling}

Et bedre ytringsklima vil etter departementets mening føre til en lavere terskel for å si fra om kritikkverdige forhold. Departementet legger til grunn at en del arbeidstakere ikke sier fra om kritikkverdige forhold på grunn av usikkerhet eller uvitenhet om når man kan si fra, hvem de kan si fra til eller hvordan de skal si fra ${ }^{61}$. Videre at det synes som lojalitetsplikten er blitt praktisert strengere enn hva lovens krav tilsier. Departementet sier her at det kan hevdes at direkte oppmuntring til varsling stimulerer til "angiveri" og en "usunn tystekultur" som er skadelig for samarbeidsklima og arbeidsmiljø ${ }^{62}$. Departementet legger imidlertid til grunn at det generelt synes å være et større problem at arbeidstakere tier enn at de sier fra i utide. Det må ut fra dette kunne konkluderes med at det er en klar målsetting at flere skal benytte varslingsretten.

\subsubsection{Skape økt forutsigbarhet}

Begrunnelsen ligger i at arbeidstaker, når han oppdager det han mener eller tror er kritikkverdig, vil ha behov for å vite hvordan han skal håndtere situasjonen. Eksempler på spørsmål som vil kunne melde seg er (i) grensene for selve retten til å varsle, (ii) hvem det skal varsles til, (iii) hvilke etiske normer virksomheten vektlegger og (iv) hva arbeidstaker skal gjøre hvis den som mottar varselet ikke gjør noe. Hvis slike spørsmål er gjennomtenkt og nedfelt i bekjentgjorte retningslinjer eller andre informasjonstiltak, vil dette gi varsleren forutsigbarhet og trygghet i en potensiell varslingssituasjon.

\footnotetext{
${ }^{60}$ Ot.prp.nr.84 (2005-2006) side 46

${ }^{61}$ Ibid. side 37

${ }^{62}$ Ibid. side 46.
} 
Et sentralt formål med varslingsrutiner er å gi arbeidstaker veiledning i en potensiell varslingssituasjon. Fordi vurderingen av om det er varslet på riktig måte vil tas i ettertid, må arbeidstaker ta risikoen i nåtid. Et sentralt spørsmål for arbeidstaker vil derfor kunne være: Hva risikerer jeg med å varsle? Arbeidstaker kan være i tvil om det overhodet dreier seg om et kritikkverdig forhold, hvilken adgang han har til å varsle, hvem varselet skal rettes til og hva som skjer hvis det ikke varsles på riktig måte. Arbeidstaker vil også kunne

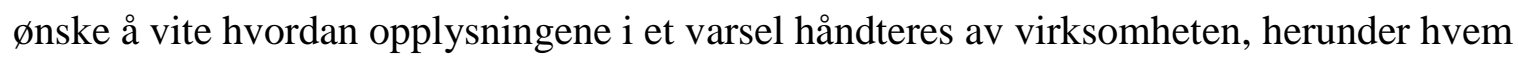
som håndterer det, og om han kan være anonym. Formålet med varslingsrutiner er å gi svar på slike spørsmål og bidra $\phi k t$ forutsigbarhet om hva som skjer etter at det er varslet.

\subsubsection{Absolutt plikt til å vurdere varslingstiltak}

Bestemmelsen oppstiller ikke i seg selv en uttrykkelig plikt til å vurdere om det er nødvendig med varslingstiltak, den sier kun at det skal legges til rette for varsling "dersom forholdene i virksomheten tilsier det". Bestemmelsen skal imidlertid forstås slik at den ilegger en absolutt plikt til å vurdere varslingstiltak. Departementet uttaler at "alle arbeidsgivere [må] i første omgang (...) vurdere om det er et behov for sarlige tiltak $i$ virksomheten" ${ }^{63}$. I følge departementet innebærer dette at plikten inntrer dersom en gjennomgang av ytringsklimaet og risikoforholdene viser at det er behov for å legge til rette for varsling ${ }^{64}$.

Når det gjelder risikoforholdene, innebærer dette at "forholdene i virksomheten " må vurderes i tilknytning til helse-, miljø- og sikkerhet på arbeidsplassen. I forarbeidene understrekes at tilrettelegging for varsling om brudd på HMS-lovgivningen er "et kjerneområde" for aml § 3-6 ${ }^{65}$. Det følger av aml § 3-1 bokstav c at arbeidsgiver allerede har en plikt til å vurdere risikoforholdene i relasjon til HMS-området.

\footnotetext{
${ }^{63}$ Ot.prp.nr.84 (2005-2006) side 47 og 54

${ }^{64}$ Ot.prp.nr.84 (2005-2006) side 47 og 54

${ }^{65}$ Ibid. side 47
} 
I følge forarbeidene skal det imidlertid vurderes risikoforhold også utenfor HMS-området, for eksempel faren for korrupsjon eller fare for liv eller helse til pasienter ${ }^{66}$. Dette har sammenheng med at skal legges til rette for varsling om "kritikkverdige forhold". Det er altså en bred risikovurdering som skal foretas, og Arbeidstilsynets varslingsveileder nevner som ytterligere eksempel at personvernet kan vurderes ${ }^{67}$.

Når det gjelder ytringsklimaet innebærer dette at arbeidsgiver skal foreta en generell vurdering av ytringsklimaet i virksomheten med sikte på hvordan intern kritikk håndteres ${ }^{68}$. Arbeidstilsynets varslingsveileder oppstiller relevante spørsmål som arbeidsgiver kan stille seg i denne forbindelse: Vet arbeidstakerne hvem de skal si fra til når de oppdager kritikkverdige forhold? Håndteres kritikk og uenighet på en skikkelig måte? Blir opplysninger om kritikkverdige forhold vurdert og unders $\emptyset \mathrm{kt}$ godt nok av de rette personene? ${ }^{69}$

Når det gjelder hvem som skal tas med i denne vurderingen, understrekes det av departementet at "de ansattes tillitsvalgte" skal trekkes inn i vurderingen ${ }^{70}$. Dette følger av sammenhengen mellom aml §§ 3-6 og 3-1 om at tilrettelegging for varsling skal gjøres i forbindelse med HMS-arbeidet. I følge Arbeidstilsynets varslingsveileder skal også eventuelt verneombud trekkes inn ${ }^{71}$. Det følger imidlertid av aml § 3-1 (1) at også "arbeidstakerne" skal tas med i det systematiske helse-, miljø- og sikkerhetsarbeidet. Når det gjelder vurderingen av ytringsklimaet er det etter min mening åpenbart at det er de ansatte selv som er best skikket til å gi uttrykk for hvordan dette oppleves. Konklusjonen

\footnotetext{
${ }^{66}$ Ibid. side 54

${ }^{67}$ Arbeidstilsynets varslingsveileder side 14

${ }^{68}$ Ot.prp.nr.84 (2005-2006) side 47

${ }^{69}$ Arbeidstilsynets varslingsveileder side 14

${ }^{70}$ Ot.prp.nr.84 (2005-2006) side 48 og 54

${ }^{71}$ Arbeidstilsynets varslingsveileder side 14
} 
må bli at de ansatte "skal" tas med i prosessen jf. aml § 3-1 (1), men at hvordan dette nærmere skal gjøres må vurderes konkret.

\subsubsection{Plikt til å iverksette varslingstiltak}

Plikten til å iverksette tiltak kan betraktes som relativ, fordi plikten først inntrer ”dersom forholdene $i$ virksomheten tilsier det”. Gjennomgangen av ytringsklimaet og risikoforholdene må altså vise at det er behov for å legge til rette for varsling ${ }^{72}$. Det er antatt i forarbeidene at aml § 3-1 "etter omstendighetene" allerede pålegger arbeidsgiver plikt til å utarbeide rutiner for varsling hvis risikovurderingen på HMS-området tilsier det ${ }^{73}$. Den uttrykkelige lovfestingen av en plikt til å legge til rette for varsling er derfor "til en viss grad" en presisering av plikter som allerede følger av loven ${ }^{74}$.

I følge departementet vil det indikere behov for tiltak "dersom konkrete tilfeller har avslфrt at saklig kritikk avvises, sanksjoneres eller ikke tas alvorlig", 75 . Bestemmelsen er imidlertid ikke ment å være "selvstigmatiserende" ved at det må foreligge konkrete mistanker om kritikkverdige forhold eller at det allerede har vært konkrete situasjoner som har utløst et behov. ${ }^{76}$.

Departementet legger i denne forbindelse til grunn at tiltak "skal" iverksettes dersom det er nødvendig "for å ivareta lovfestet varslingsplikt eller plikt til avviksrapportering" 77 . Når det gjelder lovfestet varslingsplikt, ble det imidlertid presisert i Innst.O.nr.6 (2005-2007) at dette ikke omfattes av varslingsreglene, og aml § 3-6 må derfor forstås innenfor denne rammen ${ }^{78}$. Slik jeg tolker dette, innebærer presiseringen en indirekte modifisering av

\footnotetext{
${ }^{72}$ Ibid. side 47 og 54

${ }^{73}$ Ibid. side 47

${ }^{74}$ Ibid. side 47

${ }^{75}$ Ibid. side 47

${ }^{76}$ Ot.prp.nr.84 (2005-2006) side 47

${ }^{77}$ Ibid. side 47 og 54

${ }^{78}$ Se behandlingen av dette i kapittel 1
} 
departementets uttalelse om at lovfestet varslingsplikt utløser plikt til å legge til rette for varsling. Dette vil i og for seg være naturlig, da lovgiver ikke har ment at plikten til å iverksette varslingstiltak skal omfatte alle virksomheter. Som eksempel kan det nevnes at aml § 2-3 ilegger alle arbeidstakere en varslingsplikt, og denne bestemmelsen retter seg mot alle virksomheter. Hvorvidt departementets uttalelse i lys av dette må forstås slik at ulovfestet varslingsplikt utløser en plikt til å legge til rette for varsling, er uavklart. Ut fra det jeg kan se, behandles ikke dette spørsmålet i det Øvrige rettskildematerialet. Arbeidstilsynets varslingsveileder behandler "plikt til å varsle eller plikt til avviksrapportering” som vurderingstema når det gjelder behovet for varslingstiltak, men ikke som at slik plikt utløser et absolutt krav om å iverksette varslingstiltak ${ }^{79}$.

Fordi det ikke oppstilles objektive kriterier for når plikten utløses, kan man snakke om en "selvpålagt plikt". Det skjønnsmessige elementet var også omdiskutert i høringsrunden. Arbeidstilsynet fremhevet at varselsituasjoner kan komme plutselig og uventet i alle typer virksomheter ${ }^{80}$. I følge forarbeidene skal det imidlertid ikke skal være høy terskel for å iverksette tiltak, og at det først og fremst er "ukompliserte virksomheter" med "svaert få ansatte" som vil falle utenfor ${ }^{81}$. Hva som menes med "ukompliserte virksomheter" ble ikke utdypet nærmere. I følge Arbeidstilsynets varslingsveileder vil det først og fremst være "virksomheter med få ansatte hvor det samtidig er lav risiko for økonomiske misligheter, helsefare e.l" som er unntatt fra plikten ${ }^{82}$. Dette har sammenheng med at det først og fremst er risikovurderingen som avgjør behovet for varslingstiltak, ikke antall ansatte. Et meglerfirma med få ansatte kan håndtere store verdier og slik sett være like utsatt for misligheter som virksomheter med mange ansatte.

\footnotetext{
${ }^{79}$ Arbeidstilsynets varslingsveileder side 14

${ }^{80}$ http://www.regjeringen.no/upload/kilde/asd/hdk/2005/0009/ddd/pdfv/276558-dat.pdf. Side 11.

${ }^{81}$ Ot.prp.nr.84 (2005-2006) side 47 og 48

${ }^{82}$ Arbeidstilsynets varslingsveileder side 14
} 
Aml § 3-6 skal i følge forarbeidene forstås slik at de fleste virksomhetene vil ha behov for varslingstiltak $^{83}$. Ut fra et risikoperspektiv antar jeg for eksempel at alle større private virksomheter og organisasjoner og offentlige virksomheter som kommuner, fylkeskommuner og universiteter $i$ utgangspunktet klart må sies å være omfattet av plikten. Fordi offentlig sektor håndterer store $\varnothing$ konomiske og samfunnsmessige verdier, er de særlig utsatt for skadevirkninger av for eksempel brudd på anskaffelsesregler, korrupsjon og økonomisk kriminalitet ${ }^{84}$. Jeg kan derfor ikke tenke meg at kommunene går klar av plikten. Oslo kommune begrunnet etableringen av sin varslingsordning med at "korrupsjons- og mislighetssaker har fått et markant omfang i flere av kommunens virksomheter det siste året" ${ }^{85}$. Jeg antar at man her viste til blant annet korrupsjonssaken i Undervisningsbygg i 2006, hvor en prosjektleder sammen med en leverandør tappet kommunen for nesten 3 millioner kroner ${ }^{86}$.

Hvis det er uavklart hvorvidt en virksomhet omfattes av plikten til å iverksette tiltak, vil dette kunne avklares ved en eventuell kontroll fra Arbeidstilsynet. Dette omtales senere.

\subsubsection{Gjelder intern varsling}

Plikten til å legge til rette for varsling gjelder i følge aml § 3-6 ”intern varsling”. Dette innebærer at det skal legges til rette for de ansattes varsling til for eksempel kolleger, verneombud, tillitsvalgte, representant for ledelsen eller andre $i$ virksomheten. Kritiske ytringer som er en del av den alminnelige interne kommunikasjonen i virksomheten skal regnes som intern varsling ${ }^{87}$. Hvis virksomheten har oppnevnt en ekstern advokat til å motta varsel på vegne av virksomheten, omfattes også denne som intern varsling ${ }^{88}$.

\footnotetext{
${ }^{83}$ Ot.prp.nr.84 (2005-2006) side 47-48

${ }^{84}$ For alle praktiske formål kan jeg ikke tenke meg at offentlige virksomheter vil gå klar av plikten ved en eventuell kontroll fra Arbeidstilsynet.

${ }^{85}$ Oslo kommunes byrådsvedtak 21. desember 2006 om å etablere varslingsordninger i Oslo kommune, side

1. Det kan hentes på www.oslo.kommune.no/varsling

${ }^{86}$ http://e24.no/naeringsliv/article2615000.ece

${ }^{87}$ Ot.prp.nr.84 (2005-2006) side 37
} 
Plikten omfatter altså ikke å legge til rette for ekstern varsling, da det er det "interne ytringsklimaet som skal styrkes". ${ }^{89}$ Med ekstern varsling menes uttalelser, dokumenter og lignende som gis til media, faglige forum, tilsynsmyndigheter og lignende utenfor virksomheten ${ }^{90}$. Det synes imidlertid å først og fremst være offentlig varsling det siktes til ${ }^{91}$. Med det menes varsling til media, blogging, hjemmesider og andre kommunikasjonskanaler med en udefinert mottakerkrets. Videre gjelder dette ytringer som lett kan spres til mange uten at arbeidstakeren har oversikt eller kontroll over informasjonen, som eksempel hvis det sendes ut en e-post til mottakere utenfor virksomheten ${ }^{92}$. Offentlig varsling er i forarbeidene skilt ut som en sarlig form for ekstern varsling, fordi skadepotensialet er større her enn ved intern varsling eller varsling til for eksempel tilsynsmyndigheter.

\subsubsection{Iverksetting av rutiner eller andre tiltak}

Hvis plikten til å iverksette varslingstiltak foreligger, blir spørsmålet om det er plikt til å utarbeide "rutiner for varsling" eller bare "andre tiltak". I følge departementet vil det i de fleste tilfeller hvor iverksettelse av varslingstiltak er nødvendig, være "naturlig” at det utarbeides rutiner for varsling ${ }^{93}$. Ut fra dette antar jeg at større virksomheter, for eksempel kommuner, ikke bare vil en plikt til å iverksette varslingstiltak, men også en plikt til å utarbeide varslingsrutiner.

Det er først og fremst i virksomheter med "få ansatte" at det kan være "uhensiktsmessig" med rutiner for varsling ${ }^{94}$. Jeg antar at begrunnelsen er at det i slike virksomheter kan være

\footnotetext{
${ }^{88}$ Ibid. side 46, 51 og 54

${ }^{89}$ Ibid. side 46

${ }^{90}$ Ibid. side 37

${ }^{91}$ Ibid. side 54

92 Ibid. side 40

${ }^{93}$ Ot.prp.nr.84 (2005-2006) side 46

${ }^{94}$ Ibid. side 47
} 
unødvendig med formaliserte rutiner for varsling, og at tilfredsstillende tilrettelegging kan gjøres på mer uformell måte, som for eksempel ved diskusjon om hvordan intern kritikk bør håndteres.

Innholdet i varslingsrutiner skal reflektere arbeidstakers behov for veiledning $\mathrm{i}$ en potensiell varslingssituasjon ${ }^{95}$. I det følgende spør jeg hva rutiner eller andre tiltak som et minimum må gå ut på.

\subsubsection{Hva må rutiner for varsling gå ut på?}

Aml § 3-6 presiserer ikke hva som menes med begrepet "rutiner”. Departementet ønsket verken å komme med konkrete anbefalinger eller å lovfeste konkrete krav med den begrunnelse at man "mangler gode empiriske kunnskaper om hvilke faktorer som påvirker ytringsfriheten" ${ }^{96}$. Man falt ned på at konkrete tiltak skal kunne tilpasses behovet og situasjonen i den enkelte bransje og virksomhet ${ }^{97}$.

Et utgangspunkt kan tas i to av de definisjonene på "rutiner" som oppstilles i forarbeidene 98 . En definisjon sier:

" [m]ed rutiner menes prosedyrer for varsling og håndtering av kritiske ytringer $i$ virksomheten som er nedfelt i reglementer, instrukser, avtaler, prosedyrer mv." 99.

En annen definisjon sier:

\footnotetext{
${ }^{95}$ I Arbeidstilsynets varslingsveileder side 15 sies det at faste rutiner eller fremgangsmåter vil "gi de ansatte veiledning $i$ hvordan de skal gå frem og trygghet for at de følger en akseptert fremgangsmåte”.

${ }^{96}$ Ot.prp.nr.84 (2005-2006) side 46

${ }^{97}$ Ibid. side 46

${ }^{98}$ Det oppstilles flere definisjoner med noenlunde lik formulering.

${ }^{99}$ Ot.prp.nr.84 (2005-2006) side 52
} 
"[m]ed rutiner menes ulike former for retningslinjer, instrukser, reglementer el.l. som angir når det skal varsles, virksomhetens etiske normer, hvem det kan varsles til osv." 100.

Definisjonene viser at kriteriene verken er absolutte eller uttømmende. Spørsmålet blir da: Hvor går den nedre grensen for hva som kan sies å være varslingsrutiner og som samtidig er innenfor formålet om å legge til rette for varsling? Og hva kan arbeidsgiver selv bestemme? Er det mulig å etablere noen minstekrav innenfor disse rammene uten at det kommer i konflikt med bestemmelsens ordlyd og lovgivers vilje?

For å kunne svare på dette, må man først se nærmere på hva departementet har ment med at man ikke vil komme verken med krav eller anbefalinger ${ }^{101}$. Begrunnelsen synes å være at man ikke vil legge seg opp i hvordan virksomhetene konkret utformer varslingstiltak. Det er imidlertid en vesentlig forskjell på generelle minstekrav og konkrete krav. I følge aml § 3-6 skal rutiner legge "forholdene til rette" for de ansattes varsling, og dette må være veiledende for hvilke minstekrav som kan utledes av bestemmelsen. Fordi varslingsrutiner skal være et tiltak rettet mot de ansatte, er det snakk om å beskrive prosedyrer for de ansattes varsling. Et minstekrav må derfor være at rutiner angir hvordan arbeidstakerne skal gå frem for å varsle.

Det neste spørsmålet blir om varslingsrutiner skal gjøres kjent for de ansatte. Hvorvidt dette er et krav fremgår ikke uttrykkelig av aml § 3-6. Formålet med bestemmelsen er imidlertid at det skal legges til rette for at de ansatte kan varsle, og slik jeg tolker dette må dette innebære at hvis det først er behov for varslingsrutiner så må disse også gjøres kjent for de ansatte. I tillegg er det et formål med aml § 3-6 at varslingsrutiner skal være et ytterligere virkemiddel for å bidra til at de ansatte kan avdekke kritikkverdige forhold, og hvis de ansatte ikke blir gjort kjent med hvilke prosedyrer som skal følges, vil et sentralt formål med bestemmelsen vanskelig kunne oppfylles.

\footnotetext{
${ }^{100}$ Ibid. side 54

${ }^{101}$ Ibid. side 46
} 
Departementet sier imidlertid at rutinene "bør" være " tilgjengelige og gjort kjent for alle ansatte ${ }^{102}$. Arbeidstilsynet gjentar dette i varslingsveilederen sin ${ }^{103}$. Hvorfor dette ikke er satt som et absolutt krav gis det ikke noe svar på verken i Odelstingsproposisjonen eller det etterfølgende lovforarbeidet. Det må imidlertid være innlysende at lovgiver ikke har ment at de ansatte ikke skal gjøres kjent med varslingsrutiner. I lovkommentaren til aml § 3-6 på

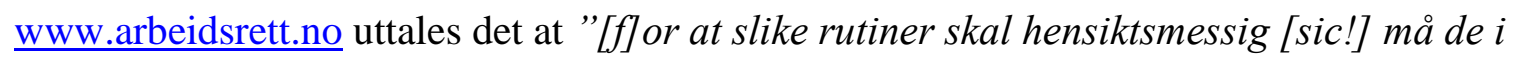
det minste vore tilgjengelige og gjort kjent for alle ansatte", ${ }^{104}$. Resultatene fra Arbeidstilsynets kontroller viser også at de setter dette som et krav ${ }^{105}$. Konklusjonen må bli at så fremt det er behov for varslingsrutiner, og slike rutiner utarbeides, så må de ansatte også gjøres kjent med disse.

Spørsmålet blir så om rutiner skal være skriftlige. Aml § 3-6 sier ikke noe om hvorvidt dette er et krav. Slik jeg tolker begrepet "rutiner" vil det, for alle praktiske formål, først og fremst være snakk om skriftlige rutiner. Definisjonen i forarbeidene om at rutiner er "retningslinjer, instrukser, reglementer" styrker en slik tolkning. Formålet om å gi arbeidstakerne $\varnothing \mathrm{kt}$ forutsigbarhet i en potensiell varslingssituasjon tilsier også at en skriftlig varslingsrutine som regel vil være den mest hensiktsmessige måten å sikre at forholdene legges til rette for varsling ${ }^{106}$. Skriftlighet har i tillegg noe med at aml § 3-6 pålegger arbeidsgiver noe, og for å dokumentere dette overfor Arbeidstilsynet er det hensiktsmessig at rutinene foreligger skriftlig.

I forarbeidene uttales det kun at rutinene "bør vare skriftlige" ${ }^{107}$. Det samme informeres det om i Arbeidstilsynets varslingsveileder ${ }^{108}$. Ut fra dette kan det spørres om det vil være

\footnotetext{
102 Ot.prp.nr.84 (2005-2006) side 47

103 Arbeidstilsynets varslingsveileder side 17

${ }^{104}$ www.arbeidsrett.no, kommentar til aml § 3-6 av Aili Stenseth Vatvedt, note 5.

105 Resultatene behandles nedenfor under "Arbeidstilsynets kontrollvirksomhet".

${ }^{106}$ Formålet om økt forutsigbarhet er behandlet ovenfor under "Formål og hensyn bak aml § 3-6" i kapittel 3.

107 Ot.prp.nr.84 (2005-2006) side 47
} 
tilstrekkelig at arbeidsgiver muntlig informerer de ansatte om at de for eksempel skal varsle "i linjen". En slik løsning vil av en rekke gode grunner neppe kunne oppfattes som holdbar eller tilstrekkelig for sikring av en ensartet informasjon til alle ansatte over tid i virksomheter med mange ansatte. Hvis varslingsrutiner ikke er skriftlige er det en reell fare for at de ansatte, for eksempel ansatte i permisjon, ikke i tilstrekkelig grad blir kjent med adgangen til, og fremgangsmåten ved, å varsle og i alle fall ikke samtidig med de andre. For det andre er lite praktisk at rutinene ikke er skriftlige. Arbeidstilsynet har satt skriftlighet som et krav i sine kontroller. Konklusjonen må bli at det for alle praktiske formål gjelder et skriftlighetskrav for varslingsrutiner, men at det må bero på en konkret vurdering hvorvidt virksomheten på tilfredsstillende måte legger til rette for varsling også uten at varslingsrutiner er gjort skriftlige.

Må varslingsrutiner angi hvor varsel skal kanaliseres? Aml § 3-6 sier ikke uttrykkelig noe om dette. Også her må det tas utgangspunkt i formålet om at det skal legges til rette for varsling. I følge en av definisjonene av varslingsrutiner menes "retningslinjer som angir (...) hvem det skal varsles til". For at varslingsrutiner skal kunne være en prosedyre for varsling, vil det åpenbart være nødvendig at det sies noe om til hvem eller til hvilken posisjon det skal varsles ${ }^{109}$. Manglende rutiner for dette kan også føre til at arbeidstakerne varsler utenfor de ønskede kanaler, for eksempel til media.

At aml § 3-6 kun pålegger en plikt til å legge til rette for "intern varsling”, må for det første sees i sammenheng med at varsling som hovedregel $b \phi r$ skje internt såfremt det er mulig og hensiktsmessig ${ }^{110}$. For det andre, når aml § 3-6 ikke pålegger en plikt til å legge til rette for offentlig (ekstern) varsling, må dette sees i sammenheng med skadepotensialet offentlig varsling kan ha for virksomheten ${ }^{111}$. For det tredje kan det nevnes at departementet uttaler at "dersom virksomheten ikke har utarbeidet (...) rutiner må

\footnotetext{
${ }^{108}$ Arbeidstilsynets varslingsveileder side 17

${ }^{109}$ En "posisjon" kan for eksempel være at man skal varsle "i linjen".

${ }^{110}$ Ot.prp.nr.84 (2005-2006) side 41

${ }^{111}$ Ibid. side 54
} 
arbeidstaker ha et større spillerom med hensyn til (...) hvordan varslingen skal skje" 112. Ut fra dette må det kunne konkluderes med at det er et ønske fra lovgiver at varslingsrutiner skal bidra til å kanalisere kritikk på en måte som både virksomhet og arbeidsmiljø er tjent med. En nødvendig forutsetning er da at varslingsrutiner informerer om hvor det skal varsles. Resultatene fra Arbeidstilsynets kontroller viser også at de setter som krav at det informeres om hvem det skal varsles til.

I denne sammenheng kan det nevnes at departementet sier at det "normalt" vil være hensiktsmessig at rutiner "også angir konkret" hvem det skal varsles til, for eksempel en navngitt person innen virksomheten eller særlig utnevnt advokat ${ }^{113}$. Dette er imidlertid ikke et absolutt krav.

Er det et krav at varslingsrutiner skal angi $h v a$ det kan varsles om og når det eventuelt skal varsles? Heller ikke her oppstilles det noe uttrykkelig krav i aml § 3-6, og jeg tar da utgangspunkt i begrepet "rutiner". For at det skal være prosedyre for varsling vil det, i tillegg til å informere om hvor det kan varsles, være naturlig at det angis $h v a$ det kan varsles om og eventuelt når det skal varsles. Når det gjelder $h v a$ det kan varsles om må dette sees i sammenheng med retten til å varsle om "kritikkverdige forhold" etter aml § 2-4 (1) og kravet i aml § 3-6 om at det skal "legges til rette" for varsling om kritikkverdige forhold. Et minstekrav må derfor være at rutiner skal opplyse om at det er kritikkverdige forhold arbeidstaker har rett til å varsle om. Når det gjelder arbeidstakernes plikt til å varsle, har jeg allerede redegjort for at varslingsreglene ikke omfatter lovfestet plikt til å varsle. Varslingsreglene omfatter imidlertid ulovfestet plikt til å varsle om uregelmessigheter eller andre kritikkverdige forhold på arbeidsplassen, og det vil være nødvendig for en reell utøvelse av en slik plikt at det informeres om når denne plikten utløses.

\footnotetext{
${ }^{112}$ Ibid. side 41

${ }^{113}$ Ibid. side 54
} 
Ut fra dette må det kunne utledes minimumskrav til varslingsrutiner: (i) De må beskrive hvordan arbeidstakerne skal gå frem for å varsle, (ii) de må gjøres tilgjengelige og kjent for de ansatte, (iii) de må angi hvor det skal varsles, (iv) de må angi hva det kan varsles om og (v) de må angi når det eventuelt skal varsles. For de fleste tilfeller må det antas at de også skal gjøres skriftlige.

\subsubsection{Hva må andre tiltak gå ut på?}

Aml § 3-6 inneholder ingen nærmere angivelse av hva "andre tiltak” skal gå ut på. Utgangspunktet er også her at det skal legges til rette for varsling. I følge forarbeidene vil hensiktsmessige tiltak kunne være å ta spørsmålet om varsling ”regelmessig opp $i$ medarbeidersamtaler, mфter, informasjon og drøftelse om hvordan intern kritikk skal håndteres osv" ${ }^{114}$. I tillegg foreslås det i Arbeidstilsynets varslingsveileder at spørsmålet om ytringsfrihet og varsling blant annet kan tas opp i "internavis eller lignende" 115.

Hva som er tilstrekkelige tiltak må bero på en konkret vurdering av om virksomheten kan sies å legge til rette for varsling. Fordi Arbeidstilsynets kontrollrapporter viser at de har samtaler med de ansatte for å finne ut om bevissthetsnivået rundt varsling, må det antas at andre tiltak som et minimum må skape bevissthet om ytringsfrihet og varsling hos de ansatte. De påleggene fra Arbeidstilsynets kontroller jeg har fått innsyn i gjaldt imidlertid kun varslingsrutiner. Jeg vet derfor ikke hvordan Arbeidstilsynet reagerer i forhold til sin veiledning her.

\footnotetext{
${ }^{114}$ Ot.prp.nr.84 (2005-2006) side 54

${ }^{115}$ Arbeidstilsynets varslingsveileder side 15
} 


\subsubsection{Konsekvenser av at plikten ikke overholdes}

\subsubsection{Arbeidstilsynets mandat og tilsynsområde}

Aml § 3-6 ilegger en offentligrettslig plikt, noe som innebærer at plikten til å iverksette varslingstiltak faller inn under Arbeidstilsynets tilsyns- og påleggskompetanse. Arbeidstilsynet kan overprøve arbeidsgivers vurdering av om det er behov for varslingstiltak. Hjemmelen for Arbeidstilsynets tilsynsmandat følger av aml § 18-1 (1), og hjemmelen for påleggskompetansen følger av aml § 18-6 (1). Arbeidstilsynet har ikke vedtakskompetanse når det gjelder aml §§ 2-4 og 2-5, jf. § 18-6 (1). Dette er privatrettslige bestemmelser, og her har tilsynet kun veiledningskompetanse.

\subsubsection{Arbeidstilsynets kontrollvirksomhet}

At aml § 3-6 ilegger en offentligrettslig plikt innebærer først og fremst at Arbeidstilsynet kan overprøve arbeidsgivers vurdering av behovet for varslingstiltak. Deretter kan Arbeidstilsynet, hvis de har fastslått at det er behov, pålegge virksomheten å iverksette tiltak. Hvis Arbeidstilsynet ikke finner varslingstiltakene tilfredsstillende, vil dette betraktes som et brudd på plikten og manglende oppfyllelse av pålegg. I pålegg kan det fastsettes en løpende tvangsmulkt jf. aml § 18-7, og forsettlig eller uaktsom overtredelse av aml § 3-6 eller Arbeidstilsynets pålegg er straffbart, jf. aml kapittel 19. Fordi Arbeidstilsynet kan overprøve arbeidsgivers vurderinger når det gjelder behovet for varslingstiltak, innebærer dette at Arbeidstilsynet i stor grad vil kunne fastlegge hvilke minstekrav som må stilles til en varslingsordning.

Til nå har Arbeidstilsynet hatt to aksjoner hvor de kontroller hvordan varslingsbestemmelsene er blitt implementert i det systematiske HMS-arbeidet ${ }^{116}$. Høsten 2007 ble det gjennomført 23 tilsyn i utvalgte interesseorganisasjoner basert på en risikovurdering. Hensikten var kartlegging, og metoden gikk ut på å sjekke om det forelå tilfredsstillende rutiner for varsling. Det var en reaksjonsprosent på nær $90 \%$, som vil si at

\footnotetext{
116 29. september 2008
} 
i ca $90 \%$ av tilfellene hadde ikke virksomheten tilfredsstillende rutiner, eller ikke rutiner i det hele tatt. I 2008 er det så langt utført 21 nye tilsyn med interesseorganisasjoner ${ }^{117}$. Samme metode ble brukt, og hensikten var å finne ut om bevisstheten rundt varslingsbestemmelsene har $\varnothing \mathrm{kt}$. I denne runden var det en reaksjonsprosent på ca $50 \%$. Det har så langt ikke kommet klager på vedtakene.

Et utvalg tilsynsrapporter fra disse tilsynene viser at Arbeidstilsynet krever både $\underline{\text { skriftlighet }} o g$ at rutinene er gjort kjent for de ansatte ${ }^{118}$. Arbeidstilsynet hadde samtaler med de ansatte for å finne ut om dette. Der hvor det ble gitt pålegg eller merknader, ble det i tillegg krevd at rutinene (i) skal inneholde opplysninger om hvem det skal varsles til, (ii) hvordan varsling skal skje dersom den aktuelle saken involverer leder, og (iii) en beskrivelse av hvordan virksomheten verner ansatte som varsler. I ett tilfelle ${ }^{119}$, hvor det var uklart hvorvidt virksomheten hadde skriftlige rutiner for varsling, ble det fra virksomhetens side forklart at varsling ville følge linjen i organisasjonen. Samtaler som Arbeidstilsynet hadde med de ansatte viste at det var "noe bevissthet" rundt varsling. Arbeidstilsynet markerte her avvik i forhold til arbeidsmiljøloven, og varslet pålegg.

Arbeidstilsynets forvaltningspraksis viser at de, på bakgrunn av sin tolkning av aml § 3-6, oppstiller en del objektive minstekrav for varslingsrutiner. Ut over dette er Arbeidstilsynet forsiktige med å si konkret hvordan plikten skal oppfylles. Minstekravene er av såpass generell art at de kan være retningsgivende for enhver virksomhet hvor plikten til å utarbeide rutiner foreligger.

\footnotetext{
117 29. september 2008

${ }^{118}$ Werner Dagsland, rådgiver i Arbeidstilsynet i Oslo og saksbehandler ved fem av disse tilsynene, har gitt meg innsyn i tilsynsrapportene fra de tilsynene han selv var med på.

${ }^{119}$ Tilsynsrapport datert 28. mai 2008
} 


\subsection{Krav etter personopplysningsloven}

\subsubsection{Varslingsrutiner og forholdet til personopplysningsloven}

Formålet med personopplysningsloven er å beskytte den enkelte mot at personvernet krenkes gjennom behandling av personopplysninger jf. popplyl § 1. Loven kommer til anvendelse når opprettelsen og anvendelsen av varslingsrutiner medfører behandling av personopplysninger "som helt eller delvis skjer med elektroniske hjelpemidler" jf. popplyl $\S 3$ (1) bokstav a. Et varslingssystem legger opp til en behandling av personopplysninger da et varsel gjerne vil inneholde informasjon om at noen har gjort noe. Det må også legges til grunn at personopplysninger blir samlet inn i unders $\varnothing$ kelsesfasen av varselet.

I tillegg lagres det meste i dag elektronisk. Datatilsynet legger til grunn at virksomhetens behandling av personopplysninger som følge av varslingstiltak har hjemmel i aml § 3-6. Med dette har virksomheten også oppfylt kravet til rettslig grunnlag for behandling av personopplysninger i popplyl $\S 8$ og $9^{120}$.

Med personopplysninger menes "opplysninger og vurderinger som kan knyttes til en enkeltperson” jf. popplyl $\S 2 \mathrm{nr}$. 1. Med sensitive personopplysninger menes opplysninger om rasemessig eller etnisk bakgrunn, politisk, filosofisk eller religiøs oppfatning, at en person har vært mistenkt, siktet, tiltalt eller dømt for en straffbar handling, helseforhold, seksuelle forhold og medlemskap i fagforeninger jf. popplyl $§ 2 \mathrm{nr} .8$.

Spørsmålet blir hvilke nærmere krav som stilles til et varslingssystem. Forarbeidene til arbeidsmiljøloven behandler ikke forholdet til personopplysningsloven i særlig grad. Departementet nevner kort forholdet til personopplysingsloven:

"[R]utinene (...) må utformes slik at kravene til opplysningenes kvalitet (\$ 11, jf. $\S \S 27$ og 28) og kravene til informasjon (\$20) blir oppfylt. (...) I tillegg må eventuelle rutiner legges opp på en slik måte at personopplysningslovens krav til datasikkerhet oppfylles (\$13 med forskrifter)." 121

\footnotetext{
${ }^{120}$ Datatilsynets varslingsveileder side 1

${ }^{121}$ Ot.prp.nr.84 (2005-2006) side 54
} 
Arbeidstilsynets varslingsveileder sier at:

"Rutinene må utformes på en måte som ivaretar personopplysningslovens krav til innsamling, lagring og bearbeiding av personopplysninger, som også gjelder opplysninger om kritikkverdige forhold knyttet til navngitte personer. (...) Den det varsles om vil ha rett til informasjon om og innsyn i opplysninger om seg selv, noe som bare unntaksvis kan nektes. Opplysningene kan ikke gjenbrukes til et formål som er uforenlige med det opprinnelige formålet. Rutinene må legges opp på en slik måte at krav til datasikkerhet oppfylles; blant annet skal opplysningene slettes etter en viss tid. Behandlingen skal meldes til Datatilsynet. Datatilsynet kan gi narmere informasjon om personvern og kravene $i$ personopplysningsloven", 122

Datatilsynets varslingsveileder gir nærmere veiledning om hvilke krav personopplysningsloven stiller i forbindelse med varslingstiltak. I hovedsak oppstilles det tre typer krav: Krav til varslingssystemet, krav til behandlingen av varsel og krav til at de ansatte skal informeres om hvordan personopplysninger behandles i forbindelse med varsling. I det følgende skal jeg nærmere gjøre rede for disse kravene.

\subsubsection{Krav til selve varslingssystemet}

\subsubsection{Meldeplikt til Datatilsynet}

Datatilsynet legger til grunn at sensitive personopplysninger om at en person har vært "mistenkt, siktet, tiltalt eller dømt for en straffbar handling" er opplysninger som ofte samles inn i forbindelse med varsling ${ }^{123}$. Behandling av sensitive personopplysninger krever i utgangspunktet konsesjon jf. popplyl § 33 (1). Som følge av at virksomheten har rettslig grunnlag for behandling av personopplysninger i forbindelse med varsling, er imidlertid behandlingen unntatt konsesjonsplikt etter personopplysningsforskriften $§ 7-16$

\footnotetext{
${ }^{122}$ Arbeidstilsynets varslingsveileder side 17

${ }^{123}$ Datatilsynets varslingsveileder
} 
jf. popplyl § 33. Bruk av personopplysninger i forbindelse med et varslingssystem er derfor kun meldepliktig til Datatilsynet, jf. personopplysningsforskriften § 7-16 (2) og popplyl $\S 31$.

Hvis virksomheten legger til rette for varsling også fra tredjepart, inntrer det derimot konsesjonsplikt. Mer om dette sier jeg i kapittel 6.

\subsubsection{Krav til informasjonssikkerhet og internkontroll}

Når det gjelder informasjonssikkerhet, skal den behandlingsansvarlige og databehandleren gjennom planlagte og systematiske tiltak sørge for tilfredsstillende informasjonssikkerhet "med hensyn til konfidensialitet, integritet og tilgjengelighet ved behandling av personopplysninger" jf. popplyl § $13^{124}$. Når det gjelder internkontroll skal den behandlingsansvarlige etablere og holde vedlike "planlagte og systematiske tiltak som er nødvendige for å oppfylle kravene i eller i medhold av denne loven, herunder sikre personopplysningenes kvalitet” jf. popplyl § 14. Kravene til informasjonssikkerhet vil inngå i de kravene som stilles til et tilfredsstillende internkontrollsystem.

I vår sammenheng må behandlingsansvarlig forstås som arbeidsgiver. Databehandler kan være intern, eller et eksternt advokatfirma som har fått i oppdrag å ta i mot varsel på vegne av arbeidsgiver. Da varslingsrutiner vil inngå som en del av det allerede eksisterende internkontrollsystemet i virksomheten, må kravene til internkontroll leses som krav til varslingsrutinene. Dette innebærer selve måten varslingsrutinene legges opp på må gi tilstrekkelig trygghet for personvernet.

\footnotetext{
${ }^{124}$ Med behandlingsansvarlig menes i følge popplyl $§ 2$ nr. 4 "den som bestemmer formålet med behandlingen av personopplysninger og hvilke hjelpemidler som skal brukes”. Med databehandler menes i følge popplyl § 2 nr. 5 ”den som behandler personopplysninger på vegne av behandlingsansvarlige”.
} 


\subsubsection{Må oppfylle kravene til informasjonssikkerhet}

Arbeidsgiver må legge opp varslingsrutiner slik at hensynene til "konfidensialitet, integritet og tilgjengelighet" sikres. Dette er altså krav som gjelder selve varslingsrutinene.

En varslingsrutine beskriver hvordan og til hvem varsling skal skje. Hensynet til konfidensialitet innebærer at varslingsrutinen må sikre at informasjon ikke kommer på avveie. Spesielt viktig er dette fordi et varsel kan innebære sensitiv personinformasjon. En varslingsrutine som for eksempel legger opp til at varsling skal skje over vanlig e-post kan innebære en fare for såkalt uautorisert innsyn. Hvis varsling skal skje over internett, må varslingskanalen krypteres eller sikres på annen måte jf. personopplysningsforskriften $\S$ 2-11 (3). Et eksempel på dette finner man i Oslo kommunes varslingsordning. Her er det, i tillegg til det interne varslingssystemet, opprettet et eksternt varslingssystem som kan benyttes både av de ansatte og publikum. Varsling til det eksterne varslingsmottaket kan blant annet skje via en sikker elektronisk varslingskanal som ligger på nettsidene til kommunen. På nettsidene advares det uttrykkelig mot varsling via e-post på grunn av "sikkerhetshensyn" ${ }^{125}$. Datatilsynet anbefaler at tilsvarende sikringstiltak også vurderes for det interne systemet ${ }^{126}$.

Varslingsrutiner må også innebære at varselet ikke behandles av flere enn nødvendig. Hvis varsling som eksempel skal skje via mellomledd, må man vurdere risikoen for at informasjonen tilflyter uvedkommende.

Hensynet til integritet innebærer at informasjonen som behandles i forbindelse med en varslingsprosess må være så korrekt som mulig. Behandlingsansvarlig har ikke lov til å behandle personopplysninger uten at de er "tilstrekkelige og relevante for formålet med behandlingen" og at de er "korrekte og oppdaterte" jf. popplyl § 11 (1) bokstav d og e. Dette innebærer blant annet at registrerte tidspunkt må være riktige, og at de registrerte

\footnotetext{
${ }^{125} \mathrm{Se}$ www.oslo.kommune.no/varsling

${ }^{126}$ Datatilsynets høringsuttalelse datert 24. mai 2007 til Fornyings- og administrasjonsdepartementets forslag til retningslinjer for varslingsrutiner i statstjenesten, side 2 .
} 
handlingene er knyttet opp mot riktig person. Datatilsynet anbefaler her signering og tidsstempling av dokumenter.

Hensynet til tilgjengelighet innebærer for det første at varslingstjenesten, hvis denne er elektronisk, må gjøres reelt tilgjengelig for de autoriserte brukerne. For det andre at det må sikres reell tilgjengelighet til informasjonen i varslene for dem som skal behandle varselet. Datatilsynet anbefaler at elektronisk lagret informasjons sikres gjennom sikkerhetskopier, slik at man ikke mister viktig informasjon ved for eksempel sletting. For arkivpliktige virksomheter stiller arkivlova med forskrifter en rekke krav som blant annet skal sikre tilgjengelighet ${ }^{127}$.

\subsubsection{Krav ved behandlingen av varsel}

\subsubsection{Hovedregelen om innsynsrett og informasjonsplikt}

Hovedregelen er at den registrerte ${ }^{128}$ har rett til innsyn i de personopplysninger som behandles i tilknytning til varselet jf. popplyl § 18. Innsynsretten omfatter både varsleren og den eller dem varselet gjelder. Den behandlingsansvarlige har som hovedregel plikt til å informere den varselet gjelder om dette jf. popplyl § 20 (1). I en varselsituasjon vil gjerne den som varselet gjelder ikke vite at det er blitt varslet. Informasjonsplikten vil derfor gjøre den registrerte oppmerksom på dette. Det vil da være naturlig at den registrerte vil ønske å vite hvilke opplysinger som er registrert på ham eller henne. Innsynsretten gjelder først og fremst personopplysningene til den registrerte. Et viktig personvernprinsipp er imidlertid at man også skal få vite hvor personopplysninger er samlet inn fra, jf. popplyl $§ 18$ bokstav e. Innsynsretten vil derfor kunne anvendes for innsyn om varslers identitet.

\footnotetext{
${ }^{127}$ Lov av 4. desember 1992 nr 126

${ }^{128}$ Med "registrert” menes i følge popplyl § 2 nr. 6 ”den som en personopplysning kan knyttes til”. I forbindelse med varsling vil dette omfatte både varsler og den eller de det varsles om.
} 
Hvis varsleren er anonym, vil ikke innsynsretten kunne anvendes for et slikt formål. Hvis varsleren derimot ønsker å stå frem, vil personvernet til den det varsles om ivaretas. Konflikt mellom innsynsrett og anonymitet oppstår først og fremst hvis varsleren er avidentifisert overfor varslingsmottaker, men forøvrig ønsker å være anonym. Varsleren kan for eksempel ha varslet til tillitsvalgt, verneombud eller til en eksternt oppnevnt advokat under forutsetning $a v$ at identiteten ikke bringes videre. I en slik situasjon blir det spørsmål om det kan gjøres unntak fra innsynsretten når det gjelder varslers identitet. Problemstillinger knyttet til dette behandles i kapittel 4.

\subsubsection{Generelle unntak fra informasjonsplikten}

Når det gjelder informasjonsplikten, ville det mest aktuelle unntaket for varslingsordningen som sådan vært popplyl § 20 (2) bokstav a om at "innsamlingen eller formidlingen av opplysningene er uttrykkelig fastsatt i lov”. Datatilsynet legger imidlertid til grunn at dette unntaket ikke kommer til anvendelse fordi behandlingen ikke er "uttrykkelig" fastsatt i lov. Som begrunnelse for dette oppgis blant annet at det vil kunne være "uklart for de ansatte om virksomheten er omfattet av kravene $i$ \$ 3-6" ${ }^{129}$. Ut over plikten til å utarbeide et varslingssystem sier ikke aml § 3-6 noe om hvorvidt det legges opp til en behandling av personopplysninger. Dette innebærer at selv om plikten til å opprette et varslingssystem er hjemlet i aml § 3-6, så har ikke selve innsamlingen og formidlingen av personopplysninger tilstrekkelig hjemmel til å begrunne et generelt unntak fra informasjonsplikten.

\subsubsection{Spesielle unntak fra informasjonsplikten og innsynsretten}

Det gjelder i følge popplyl $§ 23$ særlige unntak fra både informasjonsplikten og innsynsretten. Slike unntak må baseres på en konkret vurdering av hvert enkelt varsel. Det er særlig to aktuelle unntak. For det første hvis det gjelder opplysninger det er "påkrevd å hemmeligholde av hensyn til forebygging, etterforskning, avslфring og rettslig forf $\phi$ lgning av straffbare handlinger" jf. første ledd bokstav b. Unntaket gjelder med dette ikke

\footnotetext{
${ }^{129}$ Datatilsynets varslingsveileder, under punktet "'Informasjonsplikt".
} 
kritikkverdige forhold som er ulovlige men ikke straffesanksjonerte, uetiske eller i strid med instrukser og lignende. De fleste tilfellene av varsling vil derfor falle utenfor unntaket.

For det andre gjelder det unntak for opplysninger "det i medhold av lov gjelder taushetsplikt for" jf. første ledd bokstav d. Jeg antar at dette unntaket først og fremst vil spisses hvis varsleren er avidentifisert overfor varslingsmottaker, men ønsker å være anonym overfor arbeidsgiver. I en slik situasjon er det varslerens identitet, ikke personopplysningene til den det varsles om, som det ønskes unntak fra innsynsretten for. Problemstillinger knyttet til dette behandles i kapittel 4.

\subsubsection{Lagringstiden av personopplysningene}

Det følger av popplyl § 11 (1) bokstav e at opplysningene ikke skal lagres "lenger enn det som er nødvendig ut fra formålet med behandlingen”. Virksomheter i offentlig sektor er underlagt arkivlovas bestemmelser om dette. For andre virksomheter antar Datatilsynet at lagring i to måneder etter avslutning av undersøkelsene i saken vil være passelig ${ }^{130}$.

Datatilsynet anbefaler videre at personopplysninger som fremgår av varsler som vurderes som ubegrunnede bør slettes umiddelbart. Særlig av hensyn til personvernet for den det varsles om er det viktig at slike opplysninger ikke blir liggende i systemet.

\subsubsection{Eventuell utlevering av opplysningene}

Utlevering av personopplysninger til for eksempel politiet eller andre særlige offentlige instanser krever et gyldig behandlingsgrunnlag jf. popplyl $\S 8,9$ og 11 . For ordens skyld regnes det ikke som utlevering av personopplysninger at virksomheten har satt ut håndtering av varsel til for eksempel ekstern advokat.

\footnotetext{
${ }^{130}$ Datatilsynets varslingsveileder side 2
} 


\subsubsection{Hva skal de ansatte informeres om?}

Dokumentasjon om internkontrollsystemet skal være tilgjengelig "for de den måtte angå” jf. personopplysningsforskriften § 3-1 (2). I følge Datatilsynet innebærer dette at de ansatte som blir omfattet av en varslingsordning "skal kjenne" til hvilke rutiner arbeidsgiver har for behandling av personopplysninger i forbindelse med varslingsordningen ${ }^{131}$. Hensynet bak dette må være at en ansatt som vurderer å varsle skal vite hvordan opplysningene $\mathrm{i}$ varselet behandles. Ikke minst har det betydning for den det eventuelt blir varslet om. Relevante spørsmål en varsler vil kunne stille seg her er $(i)$ hva personopplysningene brukes til, (ii) hvor lenge opplysningene oppbevares, (iii) hvem som har tilgang til opplysningene og (iv) om det kan varsles anonymt.

Datatilsynets varslingsveileder sier imidlertid ikke noe nærmere om $h v a$ de ansatte skal informeres om. I følge seniorrådgiver Astrid Flesland hos Datatilsynet må "hva som er tilstrekkelig (...) avgjøres konkret" ${ }^{132}$. Ut fra dette må det kunne konkluderes med at det, i alle fall på det nåværende tidspunkt, ikke på generelt grunnlag kan oppstilles noen konkrete krav til hva de ansatte skal informeres om når det gjelder behandling av personopplysninger i et varsel.

\subsubsection{Konsekvenser av at pliktene ikke overholdes}

Datatilsynet har anledning til å føre kontroll med at virksomhetene har et tilfredsstillende varslingssystem vedrørende de krav personopplysingsloven med forskrift stiller.

Datatilsynet har anledning til å gi pålegg og stille vilkår jf. popplyl § 46. Datatilsynet har også anledning til å ilegge en løpende tvangsmulkt jf. popplyl § 47. I sjeldne tilfeller kan de også gå til politianmeldelse hvis vilkårene i popplyl § 48 er oppfylt. Datatilsynet opplyser imidlertid at de fleste retter seg etter de pålegg de får. I tillegg til disse tre sanksjonsmulighetene, vil Datatilsynets sannsynligvis også få mulighet til å ilegge gebyr ved overtredelser. Dette er foreslått i Ot.prp.nr.71 (2007-2008) Om lov om endringer $i$

\footnotetext{
${ }^{131}$ Datatilsynets varslingsveileder, under punktet "Andre plikter".

${ }^{132}$ E-mail 20. november 2008
} 
personopplysningsloven. Begrunnelsen ligger i at de gjeldende sanksjonsmåtene ikke har vist seg effektive nok.

Frem til i dag ${ }^{133}$ har Datatilsynet utført seks kontroller med virksomheter når det gjelder varslingssystem. Kontrollene ble utført i større virksomheter, hvorav fem i offentlig sektor. De fleste hadde $i k k e$ tilfredsstillende varslingsrutiner ${ }^{134}$.

Fordi rapportene fra disse kontrollene først vil foreligge i slutten av november 2008, har jeg ikke fått anledning til å se hvilke konkrete mangler som forelå. Jeg har imidlertid fått innsyn i Datatilsynets rutiner for tilsyn ${ }^{135}$. I korte trekk kan det sies at Datatilsynet kontrollerer hvilke rutiner virksomheten har for mottak og behandling av varsel, og om disse er innenfor området for aml § 3-6 og de krav personopplysningsloven med forskrift oppstiller. Når det gjelder anonym varsling, ble det unders $ø$ kt hvorvidt virksomheten eksplisitt lover anonymitet til varsleren og hvilke tanker virksomheten har gjort seg rundt dette når det gjelder rettssikkerhet og personvern. Det ble også unders $\varnothing k$ hvordan anonyme varsler håndteres. I tilfelle varslerens navn ble kjent for varslingsmottaker, etterspurte Datatilsynet hvilken hjemmel man eventuelt legger til grunn hvis det skal gjøres unntak fra innsynsretten. Hvis varsling kunne skje via en elektronisk kanal, ble det også undersøkt hvorvidt denne kunne medføre en fare for at anonyme varsleres identitet avsløres.

\footnotetext{
${ }^{133}$ Per 30. oktober 2008.

${ }^{134}$ Det kom frem under samtale med rådgiver i Datatilsynet Christine Ask Ottesen.

${ }^{135}$ Jeg har fătt innsyn i Datatilsynets "Grunnstamme for tilsyn - varsling - høst 2008" som viser hvilke kontrollpunkter Datatilsynet forholder seg til ved tilsyn.
} 


\section{Hva bør arbeidsgiver gjøre?}

\subsection{Innledning}

Spørsmålet er her hva arbeidsgiver $b \phi r$ gjøre for best å legge til rette for varsling. Her blir det i større grad et spørsmål om hvilke tiltak som kan begrunnes i de bakenforliggende hensynene med varslingsreglene. I forarbeidene gis det noen konkrete eksempler på hva varslingsrutiner kan eller $b \phi r$ inneholde. Arbeidstilsynets varslingsveileder gir også anbefalinger. Anbefalingene i begge forannevnte gjelder imidlertid kun intern varsling. En arbeidsgiver som ønsker å legge til rette for varsling $u t$ over de absolutte minstekrav kan også vurdere om det skal legges til rette også for varsling fra tredjepart.

Det er varslingsrutiner som behandles i dette kapitelet da forslagene til andre tiltak fra departementet og Arbeidstilsynet allerede er behandlet i forrige kapittel.

\subsection{Tiltak for intern varsling}

\subsubsection{Hva varslingsrutiner bør inneholde}

Nedenstående kan være veiledende for den arbeidsgiver som ønsker å gjøre mer enn et absolutt minimum for å oppfylle sin plikt til å legge til rette for varsling. Et utgangspunkt kan tas i departementets angivelse av det konkrete behovet for varslingsrutiner ${ }^{136}$ :

"Arbeidstakere som blir klar over forhold der de arbeider som de mener eller tror er kritikkverdige, vil gjerne ha behov for å vite hvordan de skal håndtere situasjonen. Arbeidstaker kan vare i tvil om for eksempel (grensene for) selve retten til à varsle, hvem han eller hun skal eller kan snakke med, hvilke etiske normer som er vektlagt $i$ virksomheten, hva arbeidstaker bør gjøre hvis den som mottar opplysningene ikke gjфr noe osv. Hvis svar på slike spфrsmål er gjennomtenkt og nedfelt i tilgjengelige og kjente kjøreregler i form av rutiner om varsling el.l., vil arbeidstakeren kunne føle seg tryggere på $\stackrel{\circ}{a}$ varsle om kritikkverdige forhold som oppdages. Dette vil gi arbeidstakeren stфrre

\footnotetext{
${ }^{136}$ Ot.prp.nr.84 (2005-2006) side 46
} 
forutsigbarhet med hensyn til når og hvordan det kan varsles, noe som blant annet vil kunne bidra til å legge forholdene til rette for arbeidstakers utфvelse av en plikt til avviksrapportering eller varsling."

I følge departementet vil det normalt være hensiktsmessig at varslingsrutiner konkretiserer "hvem det skal varsles til, for eksempel en navngitt person innen virksomheten, tillitsvalgt, en posisjon (for eksempel at man $i$ utgangspunktet skal gå i linjen) eller en sarlig utnevnt advokat" ${ }^{137}$. Om forholdet til de øvrige varslingsreglene sies at varslingsrutinene " $b \phi r$ reflektere adgangen til å varsle i henhold til $\$ 2-4$ ", 138 . Videre, ved anonym varsling, foreslår departementet at varslingsrutiner omfatter en ordning for dette. Hvis man sammenholder forslagene til utforming av varslingsrutiner med de absolutte kravene, kan dette gi en veiledning om utarbeidelse av varslingsrutiner ${ }^{139}$ :

- Skriftlighet

- Rutinene gjøres tilgjengelige og kjent for de ansatte

- Konkretiser til hvem eller hvilken posisjon det skal varsles

- Angir hva det kan og eventuelt skal varsles om

- Informerer om retten til å varsle, og begrensninger i dette.

- Informerer om hvordan varslere vernes

- Informerer om virksomhetens etiske plattform

- Informerer om behandling av anonyme varsler

- Informerer om behandling av personopplysninger

Varslingsveilederen til Arbeidstilsynet inneholder mer detaljert informasjon om hvordan varslingsrutiner generelt kan utformes. I tillegg inneholder varslingsveilederne fra KS, NHO og Fornyings- og Administrasjonsdepartementet (FAD) informasjon spesielt rettet mot henholdsvis kommuner og fylkeskommuner, det private næringslivet og statlige

\footnotetext{
${ }^{137}$ Ot.prp.nr.84 (2005-2006) side 54

${ }^{138}$ Ibid. side 54

${ }^{139}$ Sammenfatning av departementets merknader på side 54 i Ot.prp.nr.84 (2005-2006).
} 
virksomheter. For nærmere informasjon om hvordan virksomheter faktisk har lagt til rette for varsling kan det vises til Oslo kommune, Utenriksdepartementet, NORAD og PHARMAQ ${ }^{140}$.

\subsubsection{Særlig om tilrettelegging for anonym varsling}

\subsubsection{Innledning}

Under lovarbeidet ble det vurdert om det skulle lovfestes en rett til anonym varsling ${ }^{141}$. Det ble ingen lovfesting, men i Innst.O.nr.6 (2006-2007) s.10 står at varslingsreglene "ikke [er] til hinder for anonym varsling”. Videre ble det presisert at det jf. aml § 18-2 kan varsles anonymt til Arbeidstilsynet om kritikkverdige forhold, og at de samme krav burde gjelde også for andre tilsynsmyndigheter. Det ble også understreket at arbeidsgivers etterforskning for å finne ut hvem som har varslet anonymt "indirekte [vil] vare forbudt dersom den fører til reaksjoner mot varsleren" jf. aml § 2-5.

Forarbeidene til arbeidsmiljøloven sier det at det i forbindelse med varslingsrutiner "eventuelt [kan] vurderes om det skal etableres en ordning med anonym varsling" 142. Arbeidstilsynet gjentar noe tilsvarende i sin varslingsveileder. Datatilsynet nevner ikke anonym varsling i sin veileder, men uttaler seg om dette i høringen av FADs varslingsveileder ${ }^{143}$. Selv om uttalelsen rettes direkte rettet til FAD, uttaler Datatilsynet seg i generelle vendinger om anonym varsling, og sier at det "bør" utarbeides saksbehandlingsregler for anonym varsling, og herunder rutiner for anonym varsling til tillitsvalgte.

\footnotetext{
${ }^{140}$ www.norad.no og http://www.pharmaq.no/Ethics/index.html. De $\emptyset v r i g e$ har jeg henvisninger til ellers i oppgaven.

${ }^{141}$ Det er relativt utførlig behandlet i arbeidsgrupperapporten Ansattes ytringsfrihet, side 140-143. I Innst.O.nr.6 (2006-2007) nevnes det på side 10 og 11 under flertallets bemerkninger ${ }^{142}$ Ot.prp.nr.84 (2005-2006) side 54

${ }^{143} \mathrm{http} / / / \mathrm{www}$. datatilsynet.no/templates/Search $\quad$ 53.aspx?quicksearchquery=\%22anonym+varsling $\% 22$
} 
Det er gode grunner for å utarbeide rutiner for anonym varsling. Anonym varsling ligger i kjerneområdet for problemstillinger knyttet til varsling og personvern. Manglende rutiner rundt anonym varsling kan medføre fare for personvernet både for varsleren og for den det varsles om. Datatilsynet er generelt skeptisk til anonym varsling, og fremhever hensynet til kontradiksjon og personvernprinsippet om at man skal vite hvorfra opplysningene er samlet inn ${ }^{144}$. Datatilsynet mener at klare rutiner for dette vil kunne redusere de klare ulempene med anonym varsling, og at klare rutiner også vil sikre at anonyme varsler faktisk følges opp hvis det først er gitt anledning til dette.

Et sentralt spørsmål vedrørende tilrettelegging for anonym varsling er om det mulig å love full anonymitet, og - hvis ikke - i hvilken grad det er mulig. Det er både fordeler og ulemper med anonym varsling. Ulempene er størst når det gjelder personvernet til den det varsles om. Muligheten for anonym varsling kan kanskje stimulere til en negativ "angiverkultur" fordi det ikke blir mulig å ansvarliggjøre den som står bak varslingen ${ }^{145}$. En klar fordel med anonym varsling er imidlertid at det kan bidra til å senke terskelen for varsling ${ }^{146}$. Frykt for sanksjoner fra kolleger og arbeidsgiver er en årsak til at mange ikke varsler ${ }^{147}$

Når de gjelder de reelle mulighetene for anonym varsling, avhenger dette av hvordan selve varslingsordningen er organisert, hvordan varslingen skjer og om det er en virksomhet i offentlig eller privat sektor. I det følgende vil jeg peke på hvilke rettslige problemstillinger virksomheten særlig bør være oppmerksom på når varsleren er avidentifisert overfor varslingsmottaker men ønsker å være anonym overfor arbeidsgiver. Det er først og fremst i denne "mellomposisjonen" at spørsmålet om anonymitet og personvern spisses.

\footnotetext{
${ }^{144}$ Datatilsynets høringsuttalelse til FADs varslingsveileder, datert 24. mai 2007 side 4

145 Arbeidsgrupperapporten Ansattes ytringsfrihet side 141.

${ }^{146}$ Ibid. side 141

${ }^{147}$ Ot.prp.nr.84 (2005-2006) side 33
} 


\subsubsection{Forholdet til personopplysningsloven}

Under omtalen av informasjonsplikten og innsynsretten behandlet jeg det særlige unntaket som gjelder lovfestet taushetsplikt. Hvis varslingsmottaker er advokat, gjelder den profesjonsbestemte/kvalifiserte taushetsplikten, og hovedhjemmelen finner man i straffeloven $\S 144{ }^{148}$. Forutsetningen er at det må dreie seg om "hemmeligheter" som er betrodd " $i$ stillings medfør". Sistnevnte begrep innebærer at det bare er hvor advokat har slikt oppdrag som advokat at den kvalifiserte taushetsplikten gjelder. Taushetsplikten går her foran innsynsretten. At taushetsplikten er kvalifisert innebærer at den i tillegg går foran eventuell vitneplikt etter straffeprosessloven og tvisteloven, jf. straffeprosessloven $\S 119$ (1) og tvisteloven § 22-5 (1) ${ }^{149}$. Advokaten kan ikke gå videre med varslerens identitet uten varslerens samtykke, og brudd på taushetsplikten er straffesanksjonert, jf. straffeloven $\S 144$.

Flere virksomheter har gått inn på en ordning med eksternt varslingsmottak. Som eksempel kan nevnes varslingstjenesten til Utenriksdepartementet, hvor varsleren har anledning til å være avidentifisert overfor advokatfirmaet G-Partner ${ }^{150}$, men være anonym overfor Utenriksdepartementet ${ }^{151}$. Hvis man har en slik ordning, må også betenkelighetene ved anonym varsling reduseres fordi advokatfirmaet kan følge opp varselet ved løpende kommunikasjon med varsleren. Hvis det senere skulle vise seg nødvendig at varsleren står frem for sakens videre gang, får man også mulighet til å foreslå dette for varsleren. Hvis varselet er grunnløst eller fremsatt i ren sjikanehensikt, svekker en slik ordning neppe at dette avdekkes slik at saken kan avsluttes med minst mulig skade for den det ble varslet om.

\footnotetext{
${ }^{148}$ Almindelig borgerlig Straffelov av 22. mai $1902 \mathrm{nr} 10$

${ }^{149}$ Lov om rettergangsmåten i straffesaker av 22. mai $1981 \mathrm{nr} 25$ og lov om mekling og rettergang i sivile tvister av 17. juni $2005 \mathrm{nr} 90$

${ }^{150}$ www.g-partner.no

${ }^{151}$ http://www.regjeringen.no/nb/dep/ud/tema/Folkerett/Antikorrupsjon/varslingstjenesten.html?id=495009
} 


\subsubsection{Forholdet til forvaltningsloven}

Anonym varsling reiser ytterligere spørsmål for virksomheter som er underlagt forvaltningsloven. I følge forvaltningsloven $\S \S 18$ og 19 kan den det varsles om påberope retten til partsinnsyn for å få innsyn i varslers identitet ${ }^{152}$. Avgjørelsen av om det kan gjøres unntak for partsinnsyn må baseres på en konkret og skjønnsmessig vurdering, og i noen tilfeller vil trolig varslerens identitet ikke kunne unntas innsyn fordi det vil være av vesentlig betydning for parten å få vite dette.

Hvis man også her har inngått en avtale med et eksternt advokatfirma, vil advokatens taushetsplikt gå foran forvaltningslovens regler om innsynsrett. Det må være årsaken til at Utenriksdepartementet sier at varsleren kan være avidentifisert overfor advokatfirmaet men anonym overfor Utenriksdepartementet.

Oslo kommune, som også har inngått en avtale med et eksternt advokatfirma, har imidlertid ikke valgt en slik løsning da de er av den oppfatning at de ikke kan love full anonymitet hvis varsleren er avidentifisert overfor varslingsmottaker, selv når varslingsmottaker er advokat. Hvorfor de ikke ser det på samme måte som Utenriksdepartementet er noe uklart. Det er kanskje et uttrykk for ulik tolkning, eller usikkerhet om hvordan en eventuell rettslig avklaring av spørsmålet vil falle ut.

\subsubsection{Adgangen til anonym varsling internt}

I noen tilfeller har arbeidstaker anledning til å varsle anonymt internt i virksomheten. En ansatt kan for eksempel henvende seg til et verneombud om trakassering på arbeidsplassen. I følge aml § 2-3 (2) bokstav d plikter de ansatte i slike tilfeller å ”sørge for at arbeidsgiver eller verneombudet” blir underrettet. En slik plikt til å varsle må sies å hvile på forutsetningen om at det er adgang til å varsle anonymt ${ }^{153}$. I motsatt fall vil man kunne risikere at det ikke varsles om slike forhold.

\footnotetext{
${ }^{152}$ Lov om behandlingsmåten i forvaltningssaker av 10. februar 1967

${ }^{153}$ Arbeidsgrupperapporten Ansattes ytringsfrihet, side 142.
} 
Ved varsling til tillitsvalgte må det også være anledning til å varsle anonymt. Selv om dette verken er regulert i arbeidsmiljøloven eller i tariffavtaler, hviler tillitsmannssystemet på en forutsetning om fortrolighet ${ }^{154}$. Hvis ansatte ikke skal kunne henvende seg til tillitsvalgte $\mathrm{i}$ fortrolighet, vil dette undergrave det tillitsforholdet en slik posisjon hviler på. Dette vil også kunne bidra til at flere ikke tør varsle, noe som vil gå mot hensikten med varslingsreglene. Også her vil varslingsmottaker kunne ha anledning til å følge opp den som varsler, slik at betenkelighetene med anonym varsling reduseres.

Når det gjelder både varsling til tillitsvalgte, verneombud og eventuelt medlemmer av arbeidsmiljøutvalg, vil også det avtalerettslige elementet være en viktig forutsetning for anonymitet. Hvis varsleren her setter som betingelse for varsling at identiteten holdes skjult, vil det innebære et avtalebrudd om identiteten avsløres. Man må kunne se det slik at varsling ikke ville skjedd hvis denne forutsetningen ble brutt. Hvis det blir rettssak, og det oppstår vitneplikt for den tillitsvalgte eller verneombudet, vil imidlertid vitneplikten likevel måtte gå foran et løfte om fortrolighet.

\subsubsection{Opprettelse av et særskilt varslingsmottak}

Virksomheten kan opprette et særskilt varslingsmottak i tillegg til det ordinære. I KS sin varslingsveileder anbefales kommunene å gå for en slik løsning, og det foreslås at dette kan legges til enten et eget varslingssekretariat, varslerombud, en intern enhet eller til et advokatkontor. Fordelene med å opprette et særskilt varslingsmottak er at kanalen er objektiv og uavhengig, og at man får en sikkerhetsventil hvis de ordinære varslingskanalene enten ikke tar varselet på alvor eller hvor anses uhensiktsmessig å varsle via disse.

Oslo kommune er et eksempel på en kommune som har etablert et sentralt varslingsmottak i tillegg til de ordinære kanalene. Det sentrale varslingsmottaket i Oslo kommune betjenes

\footnotetext{
${ }^{154}$ Ibid. side 142.
} 
av et advokatkontor, og kan benyttes både av de ansatte og andre. Ordningen har per i dag fungert i vel 1,5 år. I løpet av det første året mottok kommunen drøyt 100 varsler, over halvparten anonyme, og de fleste kom til varslingsmottaket via den elektroniske web-løsningen. Jeg antar at dette skyldes at web-løsningen er enkel å bruke, og at det oppleves tryggere å varsle til en uavhengig part som i tillegg har taushetsplikt.

\subsubsection{Opprettelse av et særskilt varslingsmottak}

Virksomheten kan vurdere om den vil opprette et særskilt varslingsmottak i tillegg til det ordinære. I KS sin varslingsveileder anbefales kommunene å gå for en slik løsning, og det foreslås at dette kan legges til enten et eget varslingssekretariat, varslerombud, en intern enhet eller til et advokatkontor. Fordelene med å opprette et særskilt varslingsmottak er at kanalen er objektiv og uavhengig, og at man får en sikkerhetsventil hvis de ordinære varslingskanalene enten ikke tar varselet på alvor eller hvor det må anses uhensiktsmessig å varsle via disse. I tillegg signaliserer det en åpen bedriftskultur som tar varsling på alvor.

Oslo kommune har, som tidligere nevnt, etablert et sentralt varslingsmottak i tillegg til de ordinære kanalene. Ordningen har per i dag fungert i vel 1,5 år. I løpet av det første året mottok kommunen drøyt 100 varsel, over halvparten anonyme, og de fleste kom via den elektroniske web-løsningen til det sentrale varslingsmottaket. Jeg vil anta at dette skyldes at den elektroniske web-løsningen er enkel å bruke, og at det også oppleves tryggere å varsle til en uavhengig part som i tillegg har kvalifisert taushetsplikt. Som et annet eksempel kan nevnes Haukeland Universitetssykehus i Bergen som har opprettet et eget varslingsombud. 


\subsection{Bør det legges til rette for varsling også fra tredjepart?}

\subsubsection{Innledning}

Tilrettelegging for varsling fra tredjepart ligger utenfor anvendelsesområdet for arbeidsmiljøloven. Som jeg redegjorde for innledningsvis vil imidlertid et slikt tiltak $\phi k e$ muligheten for at kritikkverdige forhold i virksomheten avdekkes.

\subsubsection{Konsesjonsplikt til Datatilsynet}

Aml § 3-6 gir bare hjemmel for behandling av personopplysninger når det gjelder virksomhetens egne ansatte. Hvis virksomheten legger til rette for behandling av sensitive personopplysninger også fra tredjepart, kommer ikke unntaket fra konsesjonsplikten til anvendelse fordi behandlingen ikke er "fastsatt i lov", jf. personopplysningsforskriften $\S 7-16$ (2). Hovedregelen er da at behandling krever konsesjon jf. popplyl § 33 (1).

I tillegg må det oppstå konsesjonsplikt hvis en varslingstjeneste som kun er beregnet for intern varsling, likevel er lett tilgjengelig for tredjepart. Hvis man for eksempel oppretter en web-løsning for varsling på virksomhetens internettsider og ikke på intranettet, så vil dette lett kunne føre til varsel også fra andre. En slik ordning vil for det første kunne medføre en behandling av personopplysninger som ikke har hjemmel. For det andre vil det kunne komme varsel med sensitiv personinformasjon. Som eksempel kan nevnes at Oslo kommune måtte vente med å tilgjengeliggjøre det sentrale varslingsmottaket på hjemmesidene deres inntil konsesjonen var klar ${ }^{155}$.

For $\varnothing v$ vig arbeides det i skrivende stund med en endring av personopplysningsloven og personopplysningsforskriften. Det vurderes her blant annet om det skal gjøres unntak fra melde- og konsesjonsplikten på dette området.

\footnotetext{
${ }^{155}$ Dette fremgår av Oslo kommunes Retningslinjer for lokale varslingsordninger, rundskriv 11/2007 datert 13. mars 2007 , side 1 og 4 .
} 


\section{Hva kan arbeidsgiver ikke gjøre?}

\subsection{Utgangspunktet om arbeidsgivers styringsrett}

Arbeidsgivers styringsrett kan defineres som retten til å lede, fordele og kontrollere arbeidet, samt retten til å inngå arbeidsavtaler og bringe dem til opphør ${ }^{156}$. Utarbeidelse og iverksetting av varslingstiltak hører inn under arbeidsgivers styringsrett. Arbeidsgiver kan imidlertid ikke etter eget forgodtbefinnende fastlegge premissene for arbeidstakers varsling. I Ot.prp.nr.84 (2005-2006) presiserer at varslingsrutiner "ikke [kan] begrense ytringsfriheten mer enn det som følger av Grunnloven \$ 100 og arbeidsmiljфloven $\S 2-4$ " ${ }^{157}$. Det er kun varslingsrutiner dette presiseres for, og i det følgende er det først og fremst varslingsrutiner som behandles. De samme krav må imidlertid gjelde også for andre tiltak så langt det er praktisk. Også andre forhold kan begrense styringsretten uten at dette nevnes her.

\subsection{Begrensninger i arbeidsgivers styringsrett}

Forsvarlighetskravet i aml § 2-4 angir begrensninger for ansattes adgang til å varsle. Fordi arbeidsmiljøloven ikke kan fravikes til "ugunst for arbeidstaker", kan arbeidsgiver ikke sette snevrere rammer for de ansattes ytringsfrihet enn det som følger av aml § 2-4, jf. aml § 1-9. I tillegg kan varslingsrutiner heller ikke begrense ytringsfriheten mer enn hva som følger av Grl § 100 (3). Tredje ledd innebærer at inngrep i ytringsfriheten som utgangspunkt må ha grunnlag i skreven lov ${ }^{158}$. Varslingsrutiner kan med dette bare presisere eller utvide ytringsfriheten for de ansatte ${ }^{159}$.

For det første kan arbeidsgiver ikke indirekte begrense arbeidstakers lovbestemte rett til å varsle ved å utvide lojalitetsplikten, jf. aml § 1-9. Når det gjelder til hvem og til hva

\footnotetext{
156 Jakhelln (2007) side 48

${ }^{157}$ Ot.prp.nr.84 (2005-2006) side 47

${ }^{158}$ Ot.prp.nr.84 (2005-2006) side 14

${ }^{159}$ Dette presiseres også i Arbeidstilsynets varslingsveileder side 17.
} 
lojalitetsplikten retter seg, bør nok dette med god grunn kommuniseres klart i varslingsrutiner. Grunnen kan man finne i departementets vurderinger i

Ot.prp.nr.84 (2005-2006) s. 33. Departementet legger her til grunn at en begrensende faktor for den reelle ytringsfriheten "synes å vare faktiske krav, forventninger eller oppfatninger om arbeidstakernes lojalitet til sin arbeidsgiver. Disse lojalitetskravene ser ofte ut til å gå lenger enn de kravene som følger av den rettslige lojalitetsplikten”. Lojalitetsplikten synes altså å være noe misforstått i det praktiske arbeidsliv. Det kan derfor være grunn til å si noe om hvem lojalitetsplikten retter seg mot og vekten av arbeidsgivers interesser.

Lojalitetsplikten innebærer en plikt til å opptre lojalt mot den virksomhet man arbeider $i$. Arbeidsgiver kan ikke pålegge arbeidstakerne en plikt til å være lojal mot arbeidsgiver eller kollegaer personlig. Dette innebærer ikke at ytringer som går på disse personlig ikke kan omfattes av lojalitetsplikten, men ytringen må i så fall føre til at virksomheten som sådan skades, for eksempel ved omdømmetap eller dårlig arbeidsmiljø ${ }^{160}$.

Når det gjelder hvordan lojalitetsplikten skal vektes opp mot andre interesser, er vektingen blitt moderert ved lovfestingen av forsvarlighetskravet ${ }^{161}$. I Innst.O.nr.6 (2006-2007) presiseres denne interesseavveiningen ved at "hensynet til helse, miljø og sikkerhet $i$ virksomheten, til bruker/mottakere av virksomhetens tjenester og til samfunnets interesser av at varsling finner sted, [må] gis storre vekt enn hensynet til virksomhetens interne interesser" 162 . Hvis arbeidsgiver pålegger arbeidstakere en "absolutt" lojalitetsplikt overfor virksomheten, vil dette være i strid med aml § 2-4 (2).

\footnotetext{
${ }^{160}$ Nærmere om hvem lojalitetsplikten retter seg mot, se Ot.prp.nr.84 (2005-2006) side 16.

${ }^{161}$ Lojalitetsplikten er lovfestet i og med forsvarlighetskravet i aml § 2-4 (2). Forsvarlighetskravet går i hovedsak ut på at arbeidstaker må være i aktsom god tro om sannhetsgehalten i varselet. De nærmere grensedragningene rundt forsvarlighet er et omfattende tema som en ikke går nærmere inn på her. For mer informasjon, se Ot.prp.nr.84 (2005-2006) side 38-41 og 50-52.

${ }^{162}$ Flertallets merknader på side 6
} 
For det andre kan ikke arbeidsgiver begrense ytringsfriheten ved å gi offentlig ansatte instruks om taushetsplikt for informasjon som er underlagt innsynsrett. Dette blir uttrykkelig slått fast i forarbeidene i forbindelse med vurderingen av om et slikt forbud skulle lovfestes ${ }^{163}$. Offentlig ansatte vil i større grad en privat ansatte ha tilgang til informasjon om forhold som offentligheten har innsynsrett i. Arbeidsgiver kan ikke omgå innsynsretten i varslingsrutiner ved å instruere taushetsplikt omkring slike forhold.

For det tredje kan ikke arbeidsgiver pålegge arbeidstakerne å holde kriminelle eller andre alvorlige forhold internt i virksomheten ${ }^{164}$. Arbeidsgiver kan for eksempel ikke pålegge taushet omkring uriktig fakturering, skjulte bonusavtaler eller lovstridig skatte- og avgiftsbehandling. Dette behandles av departementet i forbindelse med når det ikke kan kreves at de ansatte skal varsle internt, og begrunnelsen ligger i at offentligheten kan ha en legitim interesse $\mathrm{i}$ å vite om slike forhold for å kunne føre kontroll med bruk av ressurser, lovbrudd og kvaliteten på ytelser ${ }^{165}$.

\section{De lege ferenda}

\subsection{Noen utgangspunkter}

Formålet med de nye varslingsreglene er å sørge for en "reell" styrking av varslernes kår. Hvorvidt reglene faktisk kan bidra til å bedre tilstanden er imidlertid svært omdiskutert. Dette kommer tydelig frem både i Innst.O.nr.6 (2006-2007) og i den påfølgende odelstingsdebatten hvor mindretallet uttalte at "lovforslaget ikke på noen måte skaper et

\footnotetext{
${ }^{163}$ Ot.prp.nr.84 (2005-2006) side 48-49. Det ble ikke lovfestet et slikt forbud da det ble ansett unødvendig fordi det ikke ville si mer enn hva som allerede følger av gjeldende rett.

${ }^{164}$ Arbeidstilsynets varslingsveileder side 17

165 Ot.prp.nr.84 (2005-2006) side 41. Her kommer hensynet til sannhetssøking og demokrati inn som hovedbegrunnelser bak ytringsfriheten.
} 
tilstrekkelig klart rettsvern og trygghet for varslere” ${ }^{166}$. Under et Stortingsmøte 23. mai 2008, i forbindelse med Venstres forslag om opprettelse av en varslerenhet hos Arbeidstilsynet, ble det klart at det fremdeles er politisk uenighet om vi har fått gode varslingsregler ${ }^{167}$. Det ble uttalt at man skal følge nøye med på hvordan reglene fungerer i praksis, noe som antyder at reglene ennå ikke er kodifisert rett. Per i dag er det imidlertid ingen umiddelbare planer om en evaluering av varslingsreglene ${ }^{168}$.

Det er forsvarlighetskravet i aml § 2-4 (2) som er mest omstridt. Til tross for at aml § 3-6 kanskje er den viktigste bestemmelsen, er den minst debattert. Bestemmelsen ble vedtatt tilnærmet lik forslaget. Kritikken som ble fremmet i høringsrunden vil derfor kunne være like gyldig i dag.

\section{$6.2 \mathrm{Aml} \S 3-6$}

Det skjønnsmessige elementet "dersom forholdene $i$ virksomheten tilsier det" vil kunne være en sovepute for en del virksomheter dersom arbeidsgiver og arbeidstakere blir enige om at det er tilstrekkelig med de tilsyns- og rapporteringsordningene en allerede har (revisjon, kontrollutvalg, arbeidsmiljøutvalg, HMS-regler, etisk reglement etc.) Det er dessuten prinsipielt uheldig at det legges opp til at virksomhetene selv skal avgjøre om de har ytterligere behov for å legge til rette for avdekking av interne, samfunnsskadelige forhold. Mye taler for at dette burde vært klarere regulert av lovgiver, for eksempel på linje med pålegget $\mathrm{i}$ aml $§ 7-1 \mathrm{om}$ at virksomheter som regelmessig sysselsetter mer enn 50 ansatte - eller over 20 dersom en av partene kraver det - skal ha et arbeidsmiljøutvalg. Under høringsrunden var det flere som, ved kritikk av det skjønnsmessige elementet, viste til akkurat denne bestemmelsen.

\footnotetext{
${ }^{166}$ Innst.O.nr.6 (2005-2006) side 11, under mindretallets bemerkninger. Mindretallets besto for $\emptyset \mathrm{vrig}$ av komitemedlemmene fra FrP, Høyre, Venstre og KrF.

${ }^{167}$ Stortingsmøte 23. mai 2008 kl. 10. Sak nr. 4 [11:33:40]. Innstilling fra Arbeids- og sosialkomiteen om representantforslag fra stortingsrepresentantene Odd Einar Dørum, André N. Skjelstad og Gunvald Ludvigsen om opprettelse av en varslerenhet i Arbeidstilsynet.

${ }^{168}$ Samtale 21. november 2008 med Rune Ytre Arna i Arbeids- og inkluderingsdepartementet.
} 
Aml § 3-6 kunne med fordel også formulert noen konkrete minstekrav til varslingsrutiner. Etter min mening må slike krav uansett etableres. Dette er det sannsynligvis Arbeidstilsynet med sin forvaltningspraksis som nå vil gjøre.

I denne sammenheng kan det vises til hvordan New Zealands "Protected Disclosures Act 2000" - som ikke er en rettskilde i denne sammenheng - har løst det. Section 11 oppstiller en plikt for alle offentlige arbeidsgivere til å utarbeide interne rutiner for varsling ${ }^{169}$. Her oppstilles det klare minstekrav i selve bestemmelsen om at rutiner for varsling må $(i)$ gi adekvat informasjon om hvordan det skal varsles, (ii) si konkret hvem det kan varsles til, (iii) de må bekjentgjøres og tilgjengeliggjøres vidt i virksomheten og (iv) rutinene må gjennomgås/republiseres regelmessig.

\subsection{Forholdet til personopplysningsloven}

Etter min mening er det problematisk at forholdet til personopplysningsloven ikke i større grad er behandlet i forarbeidene til arbeidsmiljøloven. Forarbeidene har fokusert primært på vern om varsleren. Det er imidlertid ikke til å komme utenom at varsling kan sette personvernet på prøve både for varsleren $o g$ den det varsles om.

Hvilke krav personopplysningsloven stiller til et varslingssystem, og i sær problemstillinger knyttet til anonym varsling, reiser komplekse spørsmål. Personopplysningsloven med forskrift synes også relativt krevende for en arbeidsgiver på grunn av sitt omfang og sin utforming. Datatilsynets varslingsveileder kunne, etter min mening, også vært tydeligere på hvilke krav som stilles til et varslingssystem. Det er for eksempel et spørsmål om det må lages et system for anonym varsling. Når slike spørsmål ikke er utredet i forarbeidene, skyves ansvaret for å løse problemene $i$ stor grad over på virksomhetene selv.

\footnotetext{
${ }^{169}$ http://www.ombudsmen.parliament.nz/internal.asp?cat=100099\#12
} 


\section{Etterord}

Innledningsvis så jeg på betydningen av varsling. Like interessant er spørsmålet om hvorfor vi akkurat nå har fått en lovfesting av adgangen til å varsle. Selv om det er for tidlig å bruke et så sterkt ord som et paradigmeskifte, kan det kanskje spørres om ikke lovfestingen representerer et mer generelt skifte i tenkningen rundt ytringsfrihet og lojalitetsplikt i ansettelsesforhold. Departementet har lagt til grunn at lojalitetskravene i det praktiske arbeidsliv ser ut til "å gå lenger enn de kravene som følger av den rettslige

lojalitetsplikten" ${ }^{170}$. Dette synes å være en erkjennelse av at lojalitetsplikten, reelt sett, har vært noe misforstått, og dermed representert en for stor begrensning i arbeidstakeres adgang til å varsle. Hvis lovfestingen bidrar til debatt og en nytenkning rundt hvem og hva man skal være lojal mot, vil dette i seg selv kunne føre til en økt forståelse for at ytringsfrihet ikke er lojalitetens motpol, men tvert i mot til at varsling om kritikkverdige forhold er lojalt.

Videre antyder den politiske debatten rundt varslingsreglene at det kan komme endringer i retning av en ytterligere styrking av varslervernet. En annen tendens, som kanskje er en del av dette bildet, kommer med den nye offentleglova som trer i kraft 1. januar 2009. Den er sterkt profilert på meroffentlighet, altså mer innsyn i hva det offentlige foretar seg. Varslingsrett og innsynsrett tjener på mange vis samme formål, ved at de bidrar til at kritikkverdige forhold i virksomheters indre liv kan avsløres og endres.

Jeg sa innledningsvis at dette er et komplekst materiale. Det er imidlertid først og fremst ett ”enkelt" spørsmål arbeidsgiver må stille seg når det skal legges til rette for varsling: Hvordan kan vi skape et godt ytringsklima? Det reelle ytringsklimaet viser seg i hvordan kritikk faktisk takles, ikke hvordan det ser ut på papiret, og profilerte varslingssaker i Norge viser at det ikke hjelper med all verdens rutiner for varsling og etiske retningslinjer hvis arbeidsgiver ikke etterlever det. Det sentrale spørsmålet for arbeidsgiver er derfor ikke hvordan tilrettelegging for varsling skal gjøres, men hvorfor dette skal gjøres.

${ }^{170}$ Ot.prp.nr.84 (2005-2006) side 33 


\section{Kilderegister}

\section{Litteratur}

Eckhoff, Torstein og Jan E. Helgesen Rettskildelare. 5.utg. Oslo, 2000.

Jakhelln, Henning Oversikt over arbeidsretten. 4. utg. Oslo, 2007.

Gedde-Dahl. Siri, Anne Hafstad og Alf Endre Magnussen Korrupsjon i Norge. Oslo, 2008.

Monsen, Per-Yngve Muldvarp i Siemens, Oslo, (2008)

Skivenes, Marit og Sissel C. Trygstad, Varslere. En bok om arbeidstakere som sier ifra! 2. utg. Bergen/Oslo, 2007.

www.rettsdata.no Kommentarer til personopplysningsloven, Dag Wiese Schartum

$\underline{\text { www.arbeidsrett.no }}$ Kommentar til arbeidsmiljøloven § 3-6 av Aili Stenseth Vatvedt

\section{Lovgivning}

\section{Norsk lovgivning}

2006 Lov om rett til innsyn i dokument i offentleg verksemd (offentleglova) av 19.mai 2006 nr. 16 (i kraft fra 1.januar 2009)

2005 Lov om arbeidsmiljø, arbeidstid og stillingsvern mv. (arbeidsmiljøloven) av 17. juni 2005 nr. 62 
2005 Lov om mekling og rettergang i sivile tvister (tvisteloven) av 17. juni $2005 \mathrm{nr} 90$

2000 Lov om behandling av personopplysninger (personopplysningsloven) av 14. april 2000

1999 Lov om styrking av menneskerettighetenes stilling i norsk rett (menneskerettsloven) av 21. mai $1999 \mathrm{nr} 30$

1992 Lov om arkiv (arkivlova) av 4. desember $1992 \mathrm{nr} 126$

1981 Lov om rettergangsmåten i straffesaker (straffeprosessloven) av 22. mai $1981 \mathrm{nr} 25$

1967 Lov om behandlingsmåten i forvaltningssaker (forvaltningsloven) av 10. februar 1967

1902 Almindelig borgerlig Straffelov (straffeloven) av 22. mai $1902 \mathrm{nr} 10$

1814 Kongeriget Norges Grundlov (Grunnloven)given i Rigsforsamlingen paa Eidsvold den 17de Mai 1814

\section{Utenlandsk lovgivning}

USA The Sarbanes Oxley Act 2002

WWW.sox.com

New Zealand

Protected Disclosures Act 2000

(http://www.ombudsmen.parliament.nz/internal.asp?cat=100099) 
South Australia $\quad$ Corporations Act 2001

http://www.austlii.edu.au/au/legis/cth/consol_act/ca2001172/index.html\#s1317aa

\section{Internasjonale konvensjoner}

EMK Europarådets konvensjon om beskyttelse av menneskerettighetene og de grunnleggende friheter (EMK) av 4. november 1950.

FN De forente nasjoners internasjonale konvensjon om sivile og politiske rettigheter av 16. desember 1966 (SP).

\section{Forskrifter}

\section{Forarbeider}

\section{Debatter og vedtak Odelstinget}

Møte i Odelstinget torsdag 16. november 2006 kl. 13. Sak nr. 1: Innstilling fra arbeids- og sosialkomiteen om lov om endringer i arbeidsmiljøloven (varsling)

\section{$\underline{\text { Innstillinger til Odelstinget }}$}

Innst.O.nr.6 (2006-2007) Om lov om endringer i arbeidsmiljøloven (varsling) 


\section{$\underline{\text { Odelstingsproposisjoner }}$}

Ot.prp.nr.49 (2004-2005) Om lov om arbeidsmiljø, arbeidstid og stillingsvern m.v. (arbeidsmiljøloven)

Ot.prp.nr.84 (2005-2006) Om lov om endringer i arbeidsmiljøloven (varsling)

Ot.prp.nr.71 (2007-2008) Om lov om endringer i personopplysningsloven m.v.

\section{Utredninger}

Arbeidsgrupperapport av 21. desember 2001 Ansattes ytringsfrihet. Av Arbeids- og sosialdepartementet i samarbeid med Justisdepartementet.

NOU 1999:27 Ytringsfrihed bør finde Sted

St.meld.nr.26 (2003-2004) Om endring av Grunnloven § 100

\section{Lovforslag}

Stortingsmøte 23. mai 2008 kl. 10. Sak nr. 4 [11:33:40]. Innstilling fra arbeids- og sosialkomiteen om representantforslag fra stortingsrepresentantene Odd Einar Dørum, André N. Skjelstad og Gunvald Ludvigsen om opprettelse av en varslerenhet i Arbeidstilsynet. 


\title{
Rettspraksis
}

\author{
Rt-2000-1811 Finanger I-dommen
}

Rt-1956-1319

\section{Elektroniske kilder}

Artikkel i Time om varslerne i FBI, WorldCom og Enron

http://www.time.com/time/subscriber/personoftheyear/2002/poyintro.html

ØKOKRIM sin trendrapport 2008

www.okokrim.no

Granskningsrapport fra Nedre Romerike Distriktsrevisjon

http://www.nrvra2.no/filarkiv/File/Granskningsrapport_NRV_RA2.pdf

Nettartikkel om korrupsjonssaken i Undervisningsbygg

http://e24.no/naeringsliv/article2615000.ece

\section{Andre kilder}

Datatilsynet høringsuttalelse til Fornyings- og administrasjonsdepartementets varslingsveileder http://www.datatilsynet.no/templates/Search 53.aspx?quicksearchquery=\%22anonym+ varsling $\% 22$ 
Arbeidstilsynets høringsuttalelse til arbeidsgrupperapporten Ansattes ytringsfrihet http://www.regjeringen.no/upload/kilde/asd/hdk/2005/0009/ddd/pdfv/276558-dat.pdf

Riksrevisjonens rapport 08/09

http://www.riksrevisjonen.no/Aktuelt/Pressemeldinger/Pressemelding_Dok_3_3_2008_200 $\underline{9 . h t m}$

\section{Varslingsveiledere og varslingstjenester}

Oslo kommunes varslingsveileder, varslingstjeneste og Retningslinjer for lokale varslingsordninger, rundskriv 11/2007

www.oslo.kommune.no/varsling

FADs varslingsveileder

http://www.regjeringen.no/nb/dep/fad/dok/Lover-ogregler/retningslinjer/2007/Retningslinjer-for-utarbeidelse-av-lokal.html?id=485618

Arbeidstilsynets varslingsveileder

http://www.arbeidstilsynet.no/c26988/brosjyre/vis.html?tid=42252

Datatilsynets varslingsveileder 10. mars 2007

http://www.datatilsynet.no/templates/article__1667.aspx

Utenriksdepartementets varslingsplakat og varslingstjeneste

http://www.regjeringen.no/nb/dep/ud/tema/Folkerett/Antikorrupsjon/varslingstjenesten.htm $\underline{1 ? \mathrm{id}=495009}$ 
Norads varslingstjeneste

http://www.norad.no/default.asp?V_ITEM_ID=11549

PHARMAQs varslingstjeneste

http://www.pharmaq.no/Ethics/index.html

Advokatfirmaet G-Partners varslingstjeneste

www.g-partner.no

\section{Personlige meddelelser}

Samtale 21. november 2008 med Rune Ytre Arna i Arbeids- og inkluderingsdepartementet.

Samtale 31. oktober 2008 med rådgiver i Datatilsynet Christine Ask Ottesen

E-mail 20. november 2008 fra seniorrådgiver Astrid Flesland i Datatilsynet

E-mail 29. september 2008 fra rådgiver i Arbeidstilsynet Werner Dagsland vedrørende tilsynsrapporter fra Arbeidstilsynet. 
